\title{
AN INVENTORY OF THE PRESENT AND PAST GLACIERIZATION OF HOME BAY AND OKOA BAY, EAST BAFFIN ISLAND, N.W.T., CANADA, AND SOME CLIMATIC AND PALAEOCLIMATIC CONSIDERATIONS
}

\author{
By J. T. Andrews, \\ (Institute of Arctic and Alpine Research and Department of Geological Sciences, University \\ of Colorado, Boulder, Colorado 80302 , U.S.A.)

\section{R. G. BARRY}

(Institute of Arctic and Alpine Research and Department of Geography, University of Colorado, Boulder, Colorado 80302, U.S.A.)

\section{and LyN Drapier}

(Geological Survey of Canada, Department of Energy, Mines and Resources, 6or Booth Street, Ottawa, Ontario, Canada)

\begin{abstract}
An air-photograph inventory of the present glacierization of areas of east Baffin Island adjoining Home Bay and Okoa Bay is described. Ice fields characterize the broad mountain summits of the former, while the latter is an area of cirque glaciers. The extent of glacierization is statistically related to various topographic parameters. It is found that there is a $4:$ I ratio between Home Bay and Okoa Bay in the area of ice as a percent of the land area above $600 \mathrm{~m}$ a.s.l. Trend-surface analyses are made of the distribution of snow-banks and of cirques (empty and with ice bodies) in the two areas. The orientation of the cirques and of the ice-field glaciers in Home Bay is also examined. $39 \%$ of empty cirques in Okoa Bay face south, whereas those with existing glaciers are restricted to orientations with azimuths between $310^{\circ}-145^{\circ}$. Neither glacier length nor the observable recession in the Home Bay area show any significant difference with regard to aspect.

Consideration of climatic parameters (snowfall and degree days) and synoptic-climatological results provide no reason for the strong contrast between the two areas. Cool, cloudy summer conditions are associated with easterly flow components that should affect both areas. A possible model for the inception of the mountain ice fields of Home Bay c. $2000-4000$ years ago is outlined and it is suggested that differential lag effects between the ice bodies in the two areas may be responsible for some of the observed difference. The many paradoxical relationships between glacierization, topography and climate in these areas, and the rather negative results, emphasize the dangers of facile palaeoclimatic interpretations.
\end{abstract}

RÉsumÉ. Un inventaire de la glaciation naturelle et passée de Home Bay et Okoa Bay, Baffin Island orientale, N.W.T., Canada, et quel ques considérations climatiques et paléoclimatiques. On décrit un inventaire par photos aériennes de la glaciation actuelle des zônes de l'est de Baffin Island avoisinant Home Bay et Okoa Bay. Des calottes de glace caractérisent les larges sommets montagneux de la première, tandis que la seconde est une zône de glaciers de cirques. L'extension de la glaciation est statistiquement liée à différents paramètres topographiques. On trouve que les surfaces englacées en pourcent de la surface totale au dessus de $600 \mathrm{~m}$ d'altitude, sont dans le rapport 4 à $\mathbf{I}$ entre Home Bay et Okoa Bay. Des analyses de tendances furent faites sur la distribution des congères et des cirques (vides ou occupés par un glacier) dans les deux zônes. On a aussi examiné l'orientation des cirques et des calottes glaciaires dans Home Bay. 39\% des cirques vides dans Okoa Bay font face au Sud, tandis que ceux qui ont gardé leur glacier en sont réduits à des orientations avec des azimuths compris entre $310^{\circ}$ et $145^{\circ}$. Ni la longueur des glaciers, ni le retrait observable des glaciers de la zone de Home Bay ne montrent quelque lien significatif avec l'exposition.

L'examen des paramètres climatiques (précipitations et degrés-jours) et de résultats synoptiques climatologiques n'apporte aucune explication de ce violent contraste entre les deux zônes. La fraicheur et la nébulosité d'été sont associées aux composantes des flux d'Est qui peuvent affecter les 2 régions. Une explication possible du commencement de la constitution de calottes de glace dans les montagnes de Home Bay il y a 2 ooo à 4000 ans est avancée et l'on suggère que des effets différemment retardés entre les glaciers de deux zônes peuvent être responsables de quelques unes des différences observées. Les nombreuses relations paradoxales entre la glaciation, la topographie et le climat dans ces zônes, et les résultats assez décourageants, soulignent les dangers des faciles interprétations paléoclimatologiques.

Zusammenfassung. Eine Bestandsaufnahme der gegenwärtigen und früheren Vergletscherung des Home Bay und Okoa Bay, Ost-Baffin-Island, N.W.T., Canada, und einige klimatische und palaeoklimatische Uberlegungen. Eine aus Luftbildern gewonnene Bestandsaufnahme der gegenwärtigen Vergletscherung von Gebieten des östlichen Baffin Islands in der Umgebung der Home Bay und Okoa Bay wird beschrieben. Eisfelder charakterisieren die breiten Berggipfel der ersten, während die zweite ein Gebiet mit Kargletschern ist. Das Ausmass der Vergletscherung wird statistisch auf verschiedene topographische Parameter bezogen. Für den prozentualen 
Anteil der vereisten Gebiete an der Landfläche höher als 600 m ü.N.N. wurde zwischen Home Bay und Okoa Bay ein Verhältnis von 4: I gefunden. In beiden Gebieten wurden Oberflächenanalysen für die Verteilung von Schneebänken und Karen (leer oder mit Eiskörpern) durchgeführt. Ebenso wurde die Orientierung der Kare und der Plateaugletscher in der Home Bay untersucht. $39 \%$ der leeren Kare in der Okoa Bay sind südorientiert, während die Kare mit bestehenden Gletschern auf Orientierungsazimute zwischen $310^{\circ}$ und $145^{\circ}$ beschränkt sind. Die Gletscher im Gebiet der Home Bay zeigen weder in ihrer Länge noch in ihrem beobachtbaren Rückgang irgendwelche signifikante Unterschiede hinsichtlich der Exposition.

Die Berücksichtigung der klimatischen (Schneefall und Schmelzperioden) und der synoptischklimatologischen Parameter liefert keine Ursache für den starken Gegensatz zwischen den beiden Gebieten. Kühle, wolkige Wetterlagen im Sommer sind mit östlichen Luftströmungen gekoppelt, die sich auf beide Gebiete auswirken sollten. Ein mögliches Modell für den Beginn der Vergletscherung auf den Bergen der Home Bay vor etwa 2 ooo-4 ooo Jahren wird entwickelt und es wird vermutet, dass differentielle Verzögerungseffekte zwischen den Eiskörpern in den beiden Gebieten für einige der beobachteten Differenzen verantwortlich sein könnten. Die vielen paradoxen Beziehungen zwischen Vergletscherung, Topographie und Klima in diesen Gebieten sowie die recht negativen Ergebnisse lassen deutlich die Gefahren cinfacher palaeoklimatischer Interpretationen erkennen.

\section{INTRODUCTION}

Ice masses cover about 153 ooo $\mathrm{km}^{2}$ of the north-eastern Canadian Arctic. The southernmost occur as small cirque glaciers in the Torngat Mountains (Forbes, 1938) at about lat. $60^{\circ}$ N. Baffin Island is moderately glacierized (Fig. I), as are the islands farther north. Inventories of the ice bodies in north-eastern Arctic Canada were first undertaken by the American Geographical Society (1958) based on the then existing maps and air photographs. A more detailed treatment involving the utilization of historical records, written and photographic, was reported by Falconer (1962) for northern Baffin Island and this work has since been extended and developed by the Glaciology Subdivision of the Inland Waters Branch, Department of Energy, Mines and Resources, Ottawa (personal communication in 1969 from C. S. L. Cmmaney) as a part of the International Hydrological Decade program to obtain a complete inventory of the world's glaciers.

It was not until the 1950 expedition of the Arctic Institute of North America to the Barnes Ice Cap (Baird, 1950) that any of these sub-polar and polar ice masses were examined. The growth of glaciological studies since that date has been slow, largely as a result of the logistical problems involved. Continuing glaciological programs presently operate on Axel Heiberg Island, Ellesmere Island and Devon Island, while on Baffin Island the Barnes Ice Cap and Decade Glacier (Sagar, Ig66; Østrem and others, 1967) are being studied. Thus out of a total glacier population of $>\mathrm{I}$ ooo, less than $\mathrm{ro}$ are under systematic observation. Basic questions concerning the representativeness of these ice bodies in terms of classifactory type, topographic milieu and meteorological regime can only be answered in the most general way.

This paper presents an analysis and interpretation of the present and past glacier (sensu lato) distribution in two contrasting sections of the east coast of Baffin Island. The first region, Home Bay (Fig. I) was selected because of field experience in the area and knowledge of its past history (Andrews and others, 1970). The area of Okoa Bay (Fig. I) was chosen because of its proximity to Home Bay and in part because a research program of the Institute of Arctic and Alpine Research is being developed there. The names Home Bay and Okoa Bay as used hereafter refer to the areas of the I : 250 ooo Canadian topographic maps (Figs. 2 and 3), not the actual sea areas.

We shall consider first the broad topographic and climatic factors that determine the present glacierization of the two areas. This theme reflects a two-fold interest: the desire to gather information on the controls of present ice distribution, and the application of the results to palaeoclimatic interpretations of evidence of past glaciation.

\section{Topography of Home Bay and Okoa Bay}

The areas under study both lie within the fiord and dissected plateau rim of eastern Baffin Island, but they differ considerably in detail (Figs. 2 and 3). Figure I shows the generalized 


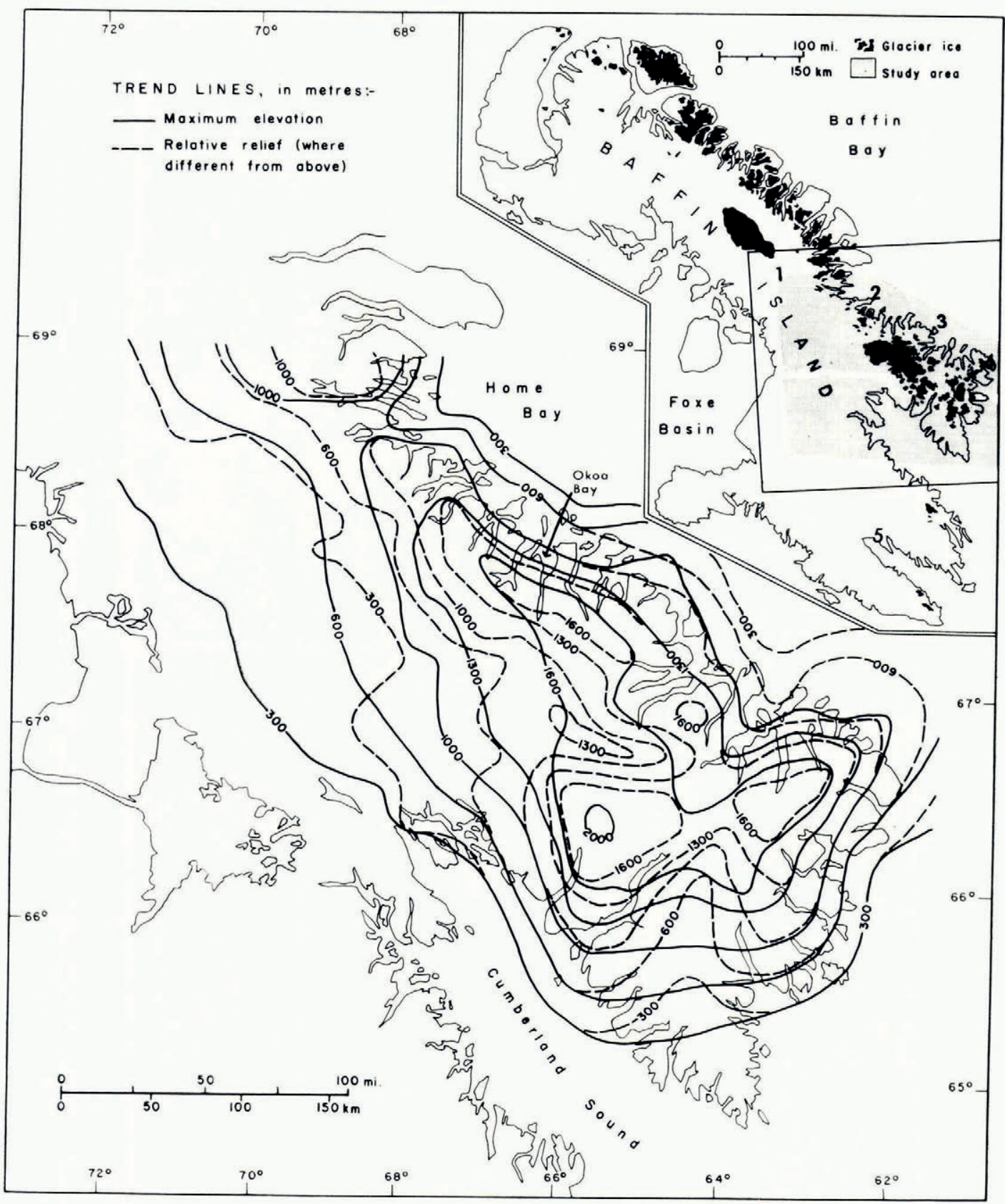

Fig. I. Contours of maximum summit elevalions and maximum relative relief for the area between Home Bay in the north and Cumberland Peninsula in the south. Inset map shows the distribution of ice masses in Baffin Island and location of weather stations I Dewar Lakes, 2 Cape Hooper, 3 Broughton Island, 4 Cape Dyer, 5 Frobisher. 


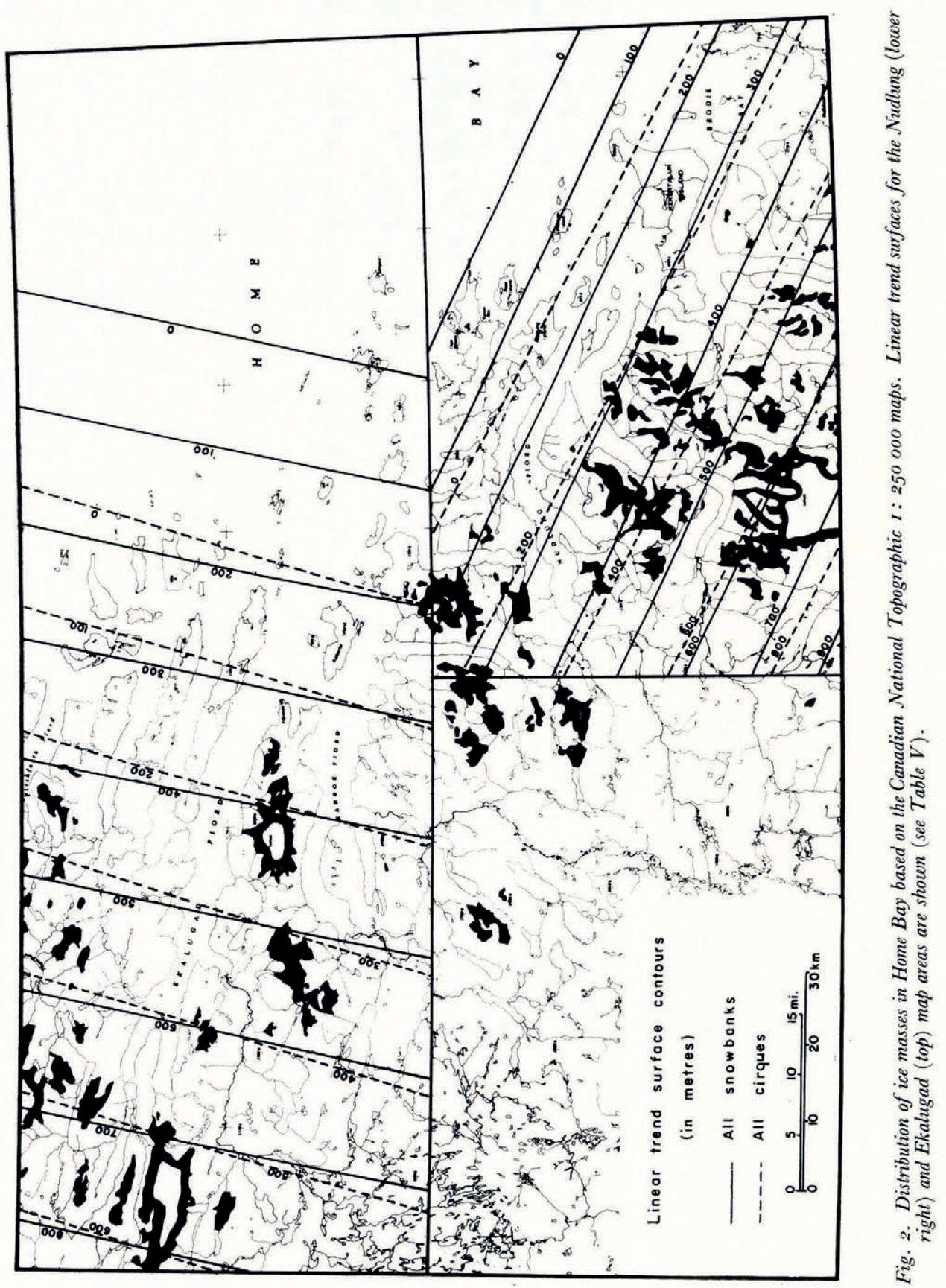


form of the summit surface and maximum relative relief over the Cumberland Peninsula. The map was constructed as follows: a grid with sides of $20 \mathrm{~km}$ was superimposed on the I : 250 ooo topographic maps (about 200 squares) and the maximum elevation and relative relief were noted in the center of each alternate square. This resulted in two data sets of Ioo individuals. The trends shown on Figure I were obtained by contouring. This procedure could result in a maximum locational error of up to $14 \mathrm{~km}$ between the actual location of a maximum and its plotted position. Figure I shows that Home Bay* lies along a saddle in the eastern mountains. Maximum elevations range from $600 \mathrm{~m}$ to $1000 \mathrm{~m}$ within the saddle.

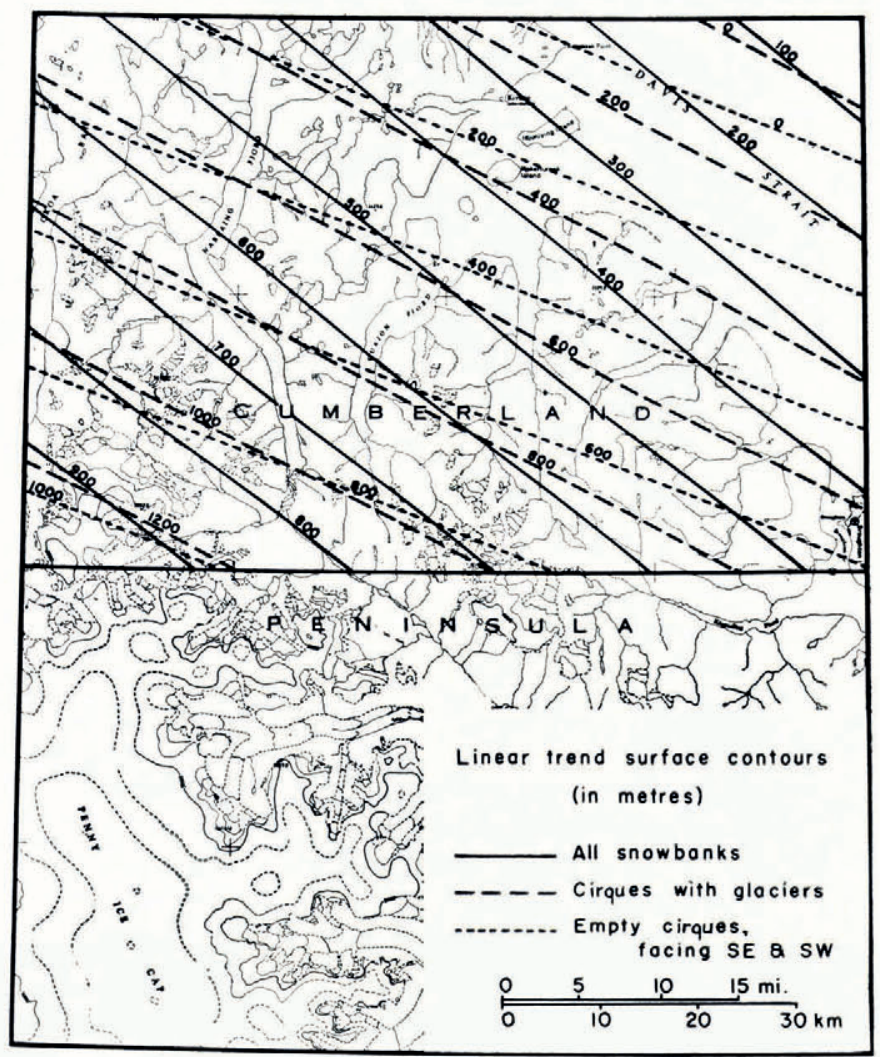

Fig. 3. Distribution of ice masses in Okoa Bay based on the Canadian National Topographic 1: 250 ooo map. Linear trend surfaces are shown (see Table IV).

In contrast maximum elevations over the Okoa Bay area vary between $800 \mathrm{~m}$ and $\mathrm{I} 600 \mathrm{~m}$, and reach 2 ooo $\mathrm{m}$ just north of Cumberland Sound. Elevations of summit surfaces slope off from this high in all directions although the gentlest slope, of about I : Ioo, is clearly that down to the south-west from the height of land. In coastal areas the lines of equal relative relief $\dagger$ are parallel to the surface elevation contours but inland from the fiord heads they diverge. Maximum relief is only about $300 \mathrm{~m}$ over much of the inland plateau.

Figures 2 and 3 , showing the distribution of ice masses in the two study areas, have been taken directly from the new I : 250 ooo topographic series. Home Bay is covered by map

* To avoid repetition, the study areas are mainly referred to as "Home Bay" and "Okoa Bay" in this paper.

$\uparrow$ We define relative relief as elevation differences, with respect to present sea-level. 
numbers $27 \mathrm{~A}$ and ${ }_{27} \mathrm{~B}$ and Okoa Bay by $26 \mathrm{P}$ (Canadian National Topographic System). It is evident that much of the glacierization of Home Bay is in the form of mountain ice fields, a reflection of the broad massive mountain topography, whereas by far the most predominant glacier form in Okoa Bay is the small cirque glacier, a consequence and cause of the alpine topography. These factors are discussed in more detail below. Figures 4 and 5 illustrate the contrasting character of the two areas and their glacierization.

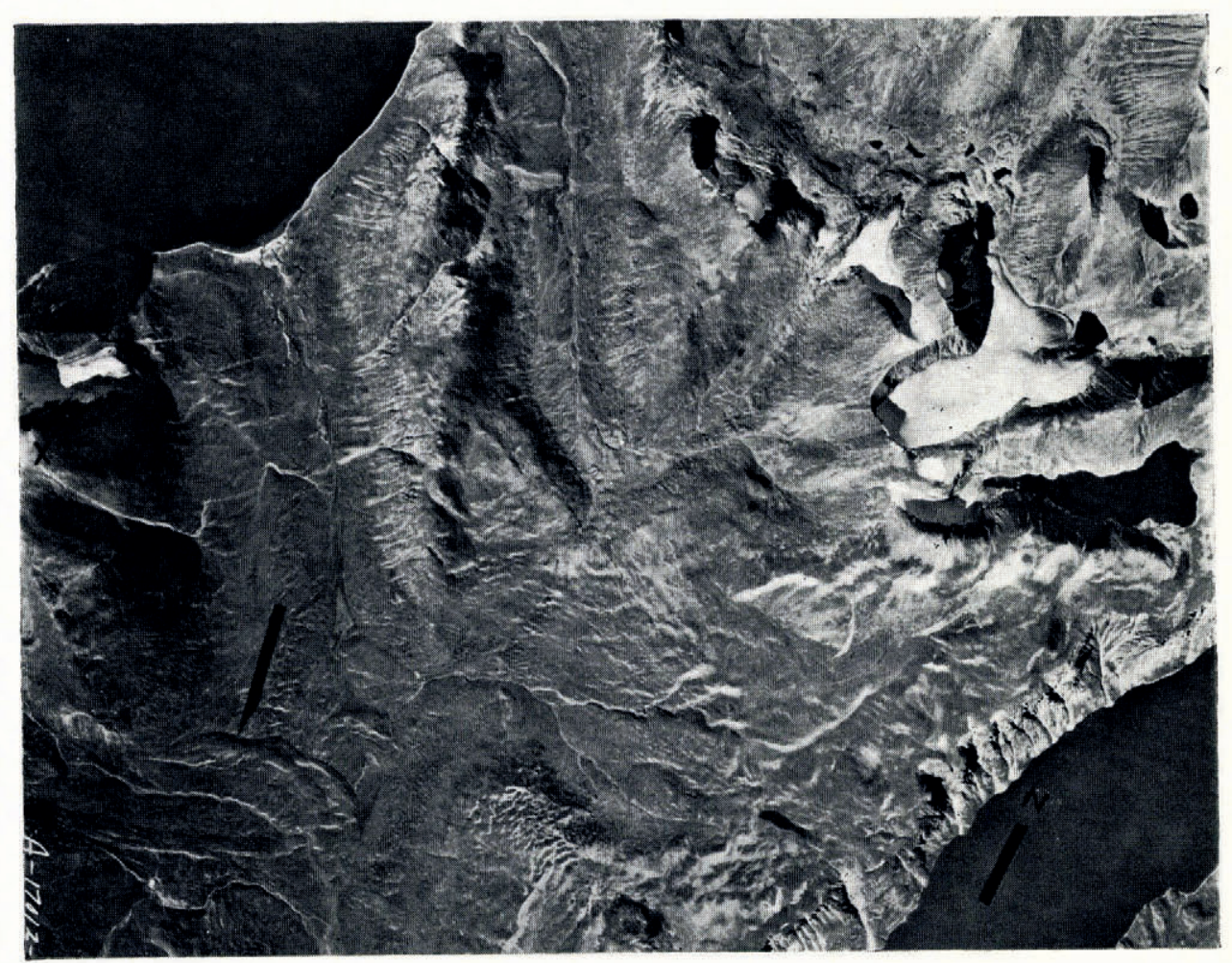

Fig. 4. Vertical air photograph (A-12012-79, National Air Photo Library, Canada) showing small cirque glaciers lying between Narpaing Fiord and Okoa Bay. The arrow points to a typical example of the extensive cirque moraines formed at as yet unknown date. Maximum elevation on peak with cross is about $I$ ooo $m$ a.s.l.

\section{Pleistocene and Recent glacial histories}

Knowledge of the Pleistocene and Recent glacial history is necessary to set our study in a time perspective. Adequate factual knowledge is available for the Home Bay area (Andrews and others, 1970), but little is known about events in Okoa Bay. However, detailed photoreconnaissance has been carried out and limited surveys have been undertaken by Andrews, and J. H. England and A. H. Kryger (personal communication in 1968).

\section{Home Bay}

Hypothetical glacier profiles, based on the assumption that the ice was grounded at the edge of the continental shelf, strongly suggest that the mountains around Nudlung Fiord were not overrun by the fiord glaciers (Mt Viewforth rises to I $550 \mathrm{~m}$ a.s.l.). Farther inland, however, the mountains attain elevations of about $900 \mathrm{~m}$ a.s.l. and were overridden at some stage by the Laurentide ice sheet. 
The outer coast emerged from the retreating glaciers about 10 ooo years ago (Andrews and others, 1970; Bryson and others, 1969). Retreat thereafter was relatively slow $\left(<27 \mathrm{~m} \mathrm{year}^{-1}\right)$ and there is good evidence that some glaciers from the inland ice sheet were still in contact with the sea about 4300 years ago (Andrews, 1969). It is concluded from field work in the Home Bay area that the fiord-glacier phase and the present mountain-ice-field phase were chronologically distinct. No evidence has been found to suggest the contemporaneity of the

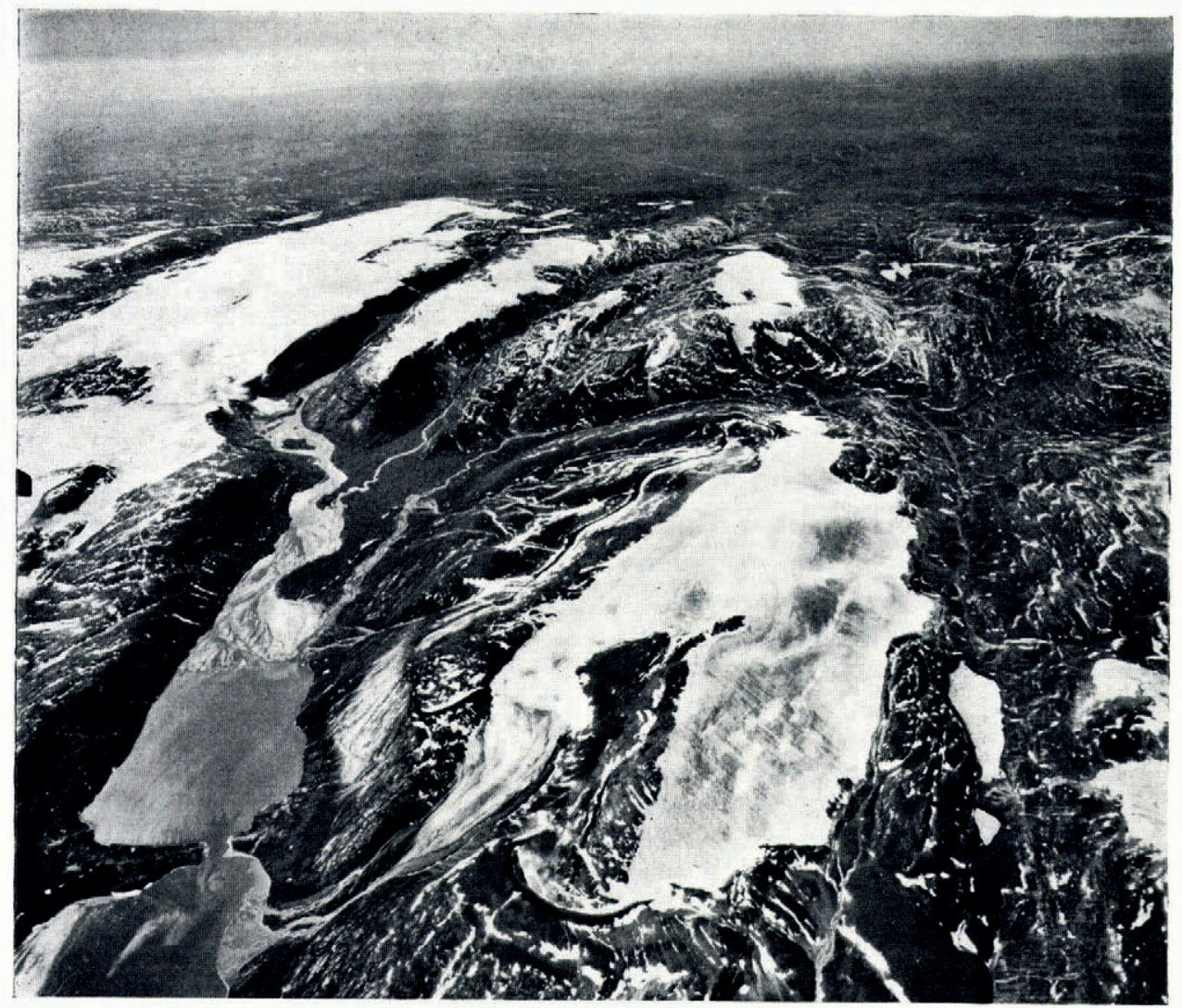

Fig. 5. Oblique air photograph ( $T_{320 L-1} 8_{5}$, National Air Photo Library, Canada) of mountain-top ice caps at the head of Ekalugad Fiord in inner Home Bay. In the left foreground a glacier from the ice cap cross-cuts the main north lateral moraine of the Ekalugad Phase dated about 8 ooo B.P. Immediately to the left again the moraine spanning the fiord is dated at $c$. 6 Ioo B.P. Maximum elevation about 1 ooo $m$ a.s.l.

mountain and fiord glaciers. This may have been the general pattern through much of east Baffin Island. On the other hand, King (1969) presents evidence for a local ice center during the maximum of the last glaciation in the high land between Itirbilung and McBeth Fiords immediately to the north. This inter-fiord areas is much higher and is morphologically more alpine than Home Bay (see Figs. 4 and 5).

Andrews and others (1970) have suggested that a major geologic/climate boundary for east Baffin Island can be placed in the interval between the final breakup of the Baffin Island ice sheet $(<4$ ooo B.P. $)$ and the expansion or re-expansion of the mountain ice fields and glaciers. This event is tentatively considered to be correlative with the re-advance of the Barnes Ice Cap about 2800 years ago (Andrews and Webber, I964). Harrison (1964, I966) 
presents evidence for correlative responses of mountain glaciers in the eastern mountains. The glaciers and ice fields experienced a period of retreat but then re-advanced to the line of the Recent terminal moraines within the last 400 years. In most cases this re-advance was greater than the sub-Atlantic re-advance. The ice masses and snow-beds that we are discussing are in part due to climatic changes several centuries old. No glaciological investigations have been carried out on any ice body within the Home Bay area. From incidental observations it is thought that the equilibrium line in any year is lower than in the mountains to the north.

\section{Okoa Bay}

Investigations of the late- and post-glacial history of the area are just beginning; only one radiocarbon date is available supplemented by a limited lichenometric survey. Airphotography interpretation suggests that during the maximum of the last glaciation, large fiord glaciers flowed toward the continental shelf. In one or two sheltered localities along the outer coast there are high cliffs of inconsolidated materials. These formations may be equivalent to those described by Løken ( 1966 ) farther north and if this is the case they must date from $>54$ oоo B.P. The physical appearance of the mountains opposite Broughton Island suggests that they were not covered by actively moving ice at the maximum of the last glaciation. Marine shells from sandy gravel above the Hudson Bay Company store on Broughton Island have been dated at $32000+\mathrm{I} 700(\mathrm{I}-3200)$. If this date is reliable it provides a maximum age for the last ice advance, although any subsequent contamination would mean that the advance was considerably older than this minimum age. The retreat of the glaciers from the fiord heads was followed at a later, and presently unknown date, by the advance of a large number of cirque glaciers. Whereas the present distribution of cirque glaciers is fairly restricted (see below), this advance involved south-facing cirque glaciers in situations where glacier ice no longer exists. With our present knowledge, the age of these local glacier moraines must be placed at either 8 ooo years old (= Cockburn Phase of Falconer, and others, I965), or 6700 years old (= Isortoq Phase, Andrews, I966), or about 4700 years old (= Flint Phase, paper by J. T. Andrews in preparation). Measurements by A. Kryger of lichen diameters on the Recent moraines of a small cirque glacier at the head of Quajon, Narpaing Fiords indicate that the outermost moraine may date from about A.D. I 200, whereas the inner moraines appear to have an age of 300 years or less.

No glaciological work has been carried out in the Okoa Bay area, although Ward and Baird (r954) calculated that in 1953 the equilibrium line on the Penny Ice Cap was at I $5^{80} \mathrm{~m}$ a.s.l.

\section{METHODOLOGY AND THE INVENTORY}

Various ice and snow masses and cirques were identified from air photographs at a scale of I : 60 ooo and were then located on topographic maps at I : I25 000 (the "blue line" prints for the I : 250 ooo National Topographic Series). Each feature was given a 6 digit location number based on a $12.5 \mathrm{~km} \times 12.5 \mathrm{~km}$ grid system arbitrarily superimposed on the map sheets. Air-photograph quality was mostly excellent.

Tables I and II illustrate the type of information that was abstracted. Areas $>\mathrm{I} \mathrm{km}^{2}$ were measured by a rolling planimeter and for smaller areas the "square-counting" method was used. Measurement errors are not easy to compute: however, our estimates are: (a) orientations $\pm 5^{\circ}$, (b) lengths, $\pm 5^{\circ} \mathrm{m}$, (c) elevations, $\pm 15 \mathrm{~m}$ for Home Bay and $\pm 5^{\circ} \mathrm{m}$ for Okoa Bay, and (d) area, $\pm 5 \%$.

\section{Definitions}

An early source of difficulty was the nomenclature to be employed. The following definitions were adopted based on Ahlmann (1948), the American Geographical Society (1958) 
TABle I. EXAmple of glacial inVentory on ICE AND SNOW MASSES

\begin{tabular}{|c|c|c|c|c|c|c|c|c|c|c|c|c|c|}
\hline \multirow[b]{2}{*}{ Feature } & \multirow[b]{2}{*}{ Location } & \multirow[b]{2}{*}{$\underset{\mathrm{m}}{\text { Maximum }}$} & \multicolumn{2}{|c|}{ Elevations } & \multirow[b]{2}{*}{$\begin{array}{c}\text { Maximum } \\
\text { in area } \\
\mathrm{m}\end{array}$} & \multirow[b]{2}{*}{$\begin{array}{l}\text { Area of } \\
\text { feature } \\
\mathrm{km}^{2}\end{array}$} & \multicolumn{3}{|c|}{ Glaciers in system } & \multicolumn{2}{|c|}{ Axes } & \multirow[b]{2}{*}{$\begin{array}{c}\text { Amount of } \\
\text { retreat } \\
\mathrm{m}\end{array}$} & \multirow[b]{2}{*}{ Remarks } \\
\hline & & & $\begin{array}{l}\text { Highest } \\
\text { margin } \\
\mathrm{m}\end{array}$ & $\begin{array}{l}\text { Lowest } \\
\text { margin } \\
\mathrm{m}\end{array}$ & & & Azimuth & $\begin{array}{l}\text { Length } \\
\mathrm{m}\end{array}$ & $\begin{array}{l}\text { Area } \\
\mathrm{km}^{2}\end{array}$ & Azimuth & $\underset{\mathrm{m}}{\text { Length }}$ & & \\
\hline $\begin{array}{l}\text { Ice cap } \\
\text { and }\end{array}$ & 131407 & I 165 & 1165 & 450 & I 165 & 14.5 & & & & $\begin{array}{ll}\text { (1) } & 059 \\
\text { (2) } & 146\end{array}$ & $\begin{array}{l}5400 \\
2700\end{array}$ & $50-100$ & $\begin{array}{l}\text { Central nunatak of } \\
0.5 \mathrm{~km}^{2}\end{array}$ \\
\hline glaciers & & & & & & & $\begin{array}{l}330 \\
147\end{array}$ & $\begin{array}{l}\text { I } 150 \\
\text { I } 8 \text { Io }\end{array}$ & $\begin{array}{l}0.7 \\
\mathrm{I}, \mathrm{I}\end{array}$ & & & 400 & \\
\hline & & & & & & & 024 & 900 & 0.5 & & & & Calving into a lake \\
\hline Ice field & 034286 & I 283 & 1283 & $95^{\circ}$ & I 337 & $\mathrm{I} .4$ & & & & 320 & 940 & & Ice fields have \\
\hline Ice field & 034295 & I 134 & I 134 & 810 & 1337 & 0.9 & & & & $33^{8}$ & I $45^{\circ}$ & & $\begin{array}{l}\text { common outlet } \\
\text { into glacier }\end{array}$ \\
\hline Glacier & & & & & & & $33^{8}$ & 2960 & & & & $>450$ & \\
\hline Ice field & 437274 & 970 & 970 & 750 & 970 & 1. 6 & & & & 012 & I 810 & & $\begin{array}{l}\text { On highest land } \\
\text { above cirque } \\
\text { backwall }\end{array}$ \\
\hline Ice patch & $32269 \mathrm{r}$ & 745 & 745 & 455 & 832 & $0.4^{8}$ & & & & & & & Faces north-east \\
\hline Ice patch & 111225 & 1120 & I 120 & 790 & 1200 & 0.52 & & & & & & & $\begin{array}{l}\text { On exposed (east) } \\
\text { slope of a } \\
\text { moraine }\end{array}$ \\
\hline Snow-bank & 803712 & 47 & & & 575 & & & & & & & & Facing north-east \\
\hline Snow-bank & $44^{8} 779$ & 318 & & & 395 & & & & & & & & $\begin{array}{l}\text { Large patch, } \\
\text { facing south-east }\end{array}$ \\
\hline
\end{tabular}

TABle II. Example of INVENTORY ON CiRQUeS

\begin{tabular}{|c|c|c|c|c|c|c|c|c|c|c|c|}
\hline Location & $\begin{array}{l}\text { Eleva } \\
\text { Top } \\
\mathrm{m}\end{array}$ & $\begin{array}{l}\text { Lions } \\
\text { Lip } \\
\mathrm{m}\end{array}$ & $\begin{array}{l}\text { Length } \\
\mathrm{m}\end{array}$ & $\underset{\mathrm{m}}{\text { Breadth }}$ & $\begin{array}{c}\text { Height of } \\
\text { backwall } \\
\text { m }\end{array}$ & $\begin{array}{l}\text { Orientation } \\
\text { of long axis }\end{array}$ & $\begin{array}{l}\text { Relation to } \\
\text { mountain mass }\end{array}$ & $\begin{array}{l}\text { Maximum elevation } \\
\text { in area }\end{array}$ & $\begin{array}{l}\text { Orientation } \\
\text { of glacier }\end{array}$ & Drowned & Remarks \\
\hline 099027 & 790 & 500 & 720 & 590 & 220 & 354 & N. and N.E. & 790 & - & No & $\begin{array}{l}\text { Ice patch, mostly } \\
\text { on north slope }\end{array}$ \\
\hline 143080 & 950 & 600 & 220 & 300 & 350 & 023 & N.E. & 950 & 023 & No & Glacier-filled \\
\hline 140159 & 720 & 600 & 300 & 615 & 90 & 012 & N. & 790 & - & No & Empty \\
\hline $182 \quad 175$ & 510 & 460 & 2000 & 2400 & 50 & 085 & E. & 780 & - & $\begin{array}{c}\text { Yes } \\
\text { (lake) }\end{array}$ & $\begin{array}{l}\text { Relic, moraines } \\
\text { down valley }\end{array}$ \\
\hline 324316 & 107 & $<0$ & 780 & 600 & $?$ & 308 & N.W. & 150 & 一 & $\begin{array}{c}\text { Yes } \\
\text { (sea) }\end{array}$ & $\begin{array}{l}\text { Backwall } \\
\text { breached }\end{array}$ \\
\hline
\end{tabular}

and the American Geological Institute (1957). It should be noted that the analysis was carried out mainly during $1966-67$, prior to any recommendations being made by the I.H.D. Committee for glacier inventories.

I. Snow-patch (synonym = snow-bed): small, permanent area of snow and ice. Often accumulates in the lee of relief irregularities. Generally about $0.1 \mathrm{~km}^{2}$.

2. Ice patch: small independent area of ice showing no signs of movement. Located in a variety of positions and generally $<2.0 \mathrm{~km}^{2}$.

3. Glacier: individual tongue or lobe of ice showing movement.

4. Ice field: continuous area of ice and snow, of lesser extent and on land of greater relief than an ice cap. Generally $<10.0 \mathrm{~km}^{2}$. (Ahlmann calls this a highland glacier or transection glacier.)

5. Ice cap: ice and snow covering a large section of land of moderate relief. Generally $>$ I0.0 $\mathrm{km}^{2}$ and moving out in all directions from the central area (Ahlmann calls this a glacier cap).

\section{General Gomparison of the glacierization of the two areas}

A valid comparison of the extent of glacierization in the two study areas must take into account differences in size of the two areas. Figure 2 includes an area of $13 \times 10^{3} \mathrm{~km}^{2}$ of which $63 \%$ is land. The Okoa Bay area (Fig. 3) in contrast covers only $4.7 \times 10^{3} \mathrm{~km}^{2}$ of which $71 \%$ is land. A fuller set of statistics is given as Table III. The most significant figures are those that express the area of ice as a per cent of the land area and, more particularly, the area of ice as a per cent of the area of land higher than $600 \mathrm{~m}$ a.s.l. In the first case the ratio between Home 
Bay and Okoa Bay is $12: \mathrm{I}$, and in the second $4: \mathrm{I}$. The comparison of ice coverage with respect to high ground most clearly demonstrates the contrast in glacierization of the two areas. This point is discussed further below.

Figure 6 presents frequency histograms of ice types. Ice patches are of approximately equal numbers in both areas although their topographic location is somewhat different. In Home Bay they occur as thin patches on, or on the side of, mountain summits, whereas in Okoa Bay they occur more characteristically in cirques. Individual glaciers originating from cirques are virtually absent from Home Bay whereas in Okoa Bay they represent the major ice types. In contrast Home Bay has many more ice fields, both in area and number. These are mainly located in the south-east (Nudlung map) area of Figure 2. Both the degree of dissection and the summit elevations decline westward in Home Bay and the large ice masses in the north-west area of Figure 2 are categorized as ice caps, a type that is not found in Okoa Bay.

TABle III. Home BAY

$\begin{array}{lcc} & \begin{array}{c}\text { Area } \\ \mathrm{km}^{2}\end{array} & \text { Per cent } \\ \text { Total area } & 13000 & \\ \text { Area land } & 8190 & 63 \\ \text { Area sea } & 4810 & 37 \\ \text { Area ice: area land } & 504 & 6 \\ \text { Area }>600 \mathrm{~m} \text { : area land } & 135^{\circ} & \mathrm{I} 6.5 \\ \text { Area ice: area }>600 \mathrm{~m} & & 37.5\end{array}$

OKOA BAY

$\begin{array}{lcc} & \begin{array}{c}\text { Area } \\ \mathrm{km}^{2}\end{array} & \text { Per cent } \\ \text { Total area } & 4700 & \\ \text { Area land } & 3320 & 71 \\ \text { Area sea } & 1380 & 29 \\ \text { Area ice: area land } & 63 & 0.5 \\ \text { Area }>600 \mathrm{~m} \text { : area land } & 745 & 22.4 \\ \text { Area ice: area }>600 \mathrm{~m} & & 8.5\end{array}$

A commentary on these data is appropriate at this point. Okoa Bay has higher mountains and a greater relative area above $600 \mathrm{~m}$ a.s.l. than Home Bay and yet the glacierization of Okoa Bay is mainly confined to cirque glaciers, suggesting the importance of local "snowfence" effects for collecting snow in topographic hollows. Thus although elevation is important in Home Bay, the topographic effects on snow distribution are much less evident than in Okoa Bay.

\section{IMPORTANCE OF SUMMIT ELEVATIONS AND AREA ABOVE $600 \mathrm{~m}$ FOR GLACIERIZATION}

The various association between summit elevation, area of ice, area of land above $600 \mathrm{~m}$, etc. are of interest. Figures 7 and 8 illustrate graphs of these relationships. The rationale for choosing the $600 \mathrm{~m}$ level was the realization that the elevation appeared as a critical lower limit to the occurrence of ice caps within Home Bay. Subjective study of the data pointed to the interrelationships of mountain area, elevation, and the presence or absence of ice. Manley (1955) has stressed the critical constraint of the summit area on potential glacier location and most of the methods for determining the "glaciation limit" (Østrem, I966; Weidick, I968) are based on a similar premise, that is, that the area/elevation value for a particular summit (i.e. the shape of the summit) controls glacierization.

We next examine the data so that changes in elevation with distance are excluded; the analysis does not therefore consider climatic or other gradients. 
Figures $7(\mathrm{a})$ and $8(\mathrm{a})$ show the relationship between the area available for glacierization $x)$ and the actual area of ice $(y)$. The least-squares equation for Okoa Bay is

and for Home Bay is

$$
y=0.174 x-0.753 \mathrm{~km}^{2}, \quad\left(r^{2}=60.4 \%\right)
$$

$$
y=0.488 x-0.79 \mathrm{I} \mathrm{km}^{2}, \quad\left(r^{2}=6 \mathrm{r} .6 \%\right)
$$

where $r^{2}$ is the coefficient of determination (the percentage of the total variance accounted for by the regression equation). Intercepts on the two graphs are similar but the area of ice in relation to the area of land over $600 \mathrm{~m}$ in Home Bay exceeds that for Okoa Bay by a factor of 2.8 .

OKOA BAY
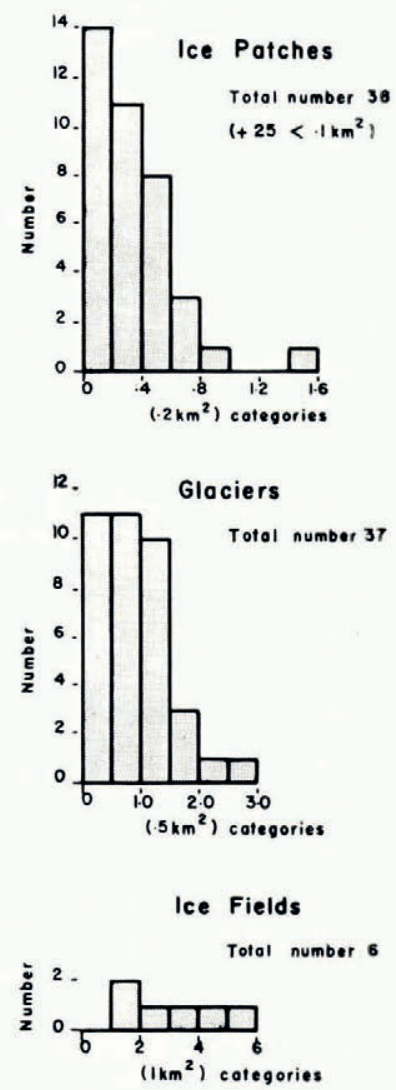

HOME BAY

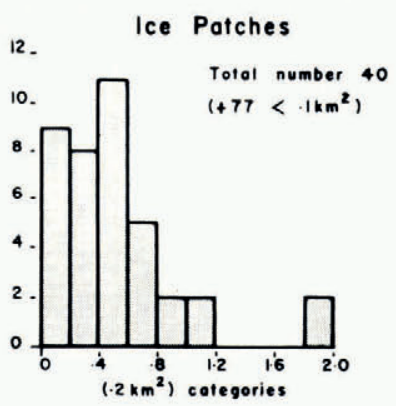

12. Ice Fields

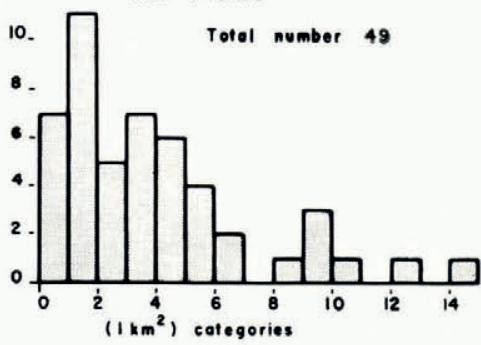

lce Caps

Total number 9

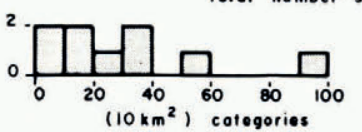

Fig. 6. Histogram of the frequency of occurrence of the different types of ice mass in Home Bay and Okoa Bay.

The 'shape' of the mountains can be expressed as a ratio of elevation to area, where the area refers to land above $600 \mathrm{~m}$ a.s.l., so that the ratio increases as a mountain becomes more and more peaked. One obvious problem with the use of such a ratio is that it is independent of the absolute values for elevation and area. Figures $7(\mathrm{~b})$ and $8(\mathrm{~b})$ show the relationship between the "shape" of the mountains and the area of ice. Both graphs show a sharply inflected relationship with the area of ice decreasing rapidly as a function of the "shape" index for values greater than $100 \times \mathrm{IO}^{-6} \mathrm{~m}^{-1}$, (i.e. a summit elevation $\approx 800 \mathrm{~m}$ for an area above $600 \mathrm{~m} \approx 8 \mathrm{~km}^{2}$ ). 
The analysis is extended by Figures $7(\mathrm{c})$ and $8(\mathrm{c})$. The presence or absence of glacierization on a particular mountain is considered to be a function of area of land above $600 \mathrm{~m}$ and the "shape" ratio. Of particular interest are the combinations of area and shape that impose limits on the presence or absence of glacier ice. Figure 7 (c) shows that an elevation/area index of about $365 \times 10^{-6} \mathrm{~m}^{-1}$ and an area of about $2 \mathrm{~km}^{2}$ is the upper limit for glacierization in Home Bay. The limiting elevation, therefore, is $730 \mathrm{~m}$. However, the gradient is very gentle in this sector of the graph. Conversely, topography with an index of less than $30 \times 10^{-6} \mathrm{~m}^{-1}$ and an area of greater than $25 \mathrm{~km}^{2}$ (i.e. summit elevation $\approx 750 \mathrm{~m}$ ) is always glacierized. Similar, but slightly lower limits occur in Okoa Bay (Fig. 8(c)). Thus, summit elevations on either limit are similar and it is the area of the high ground that appears to be critical.
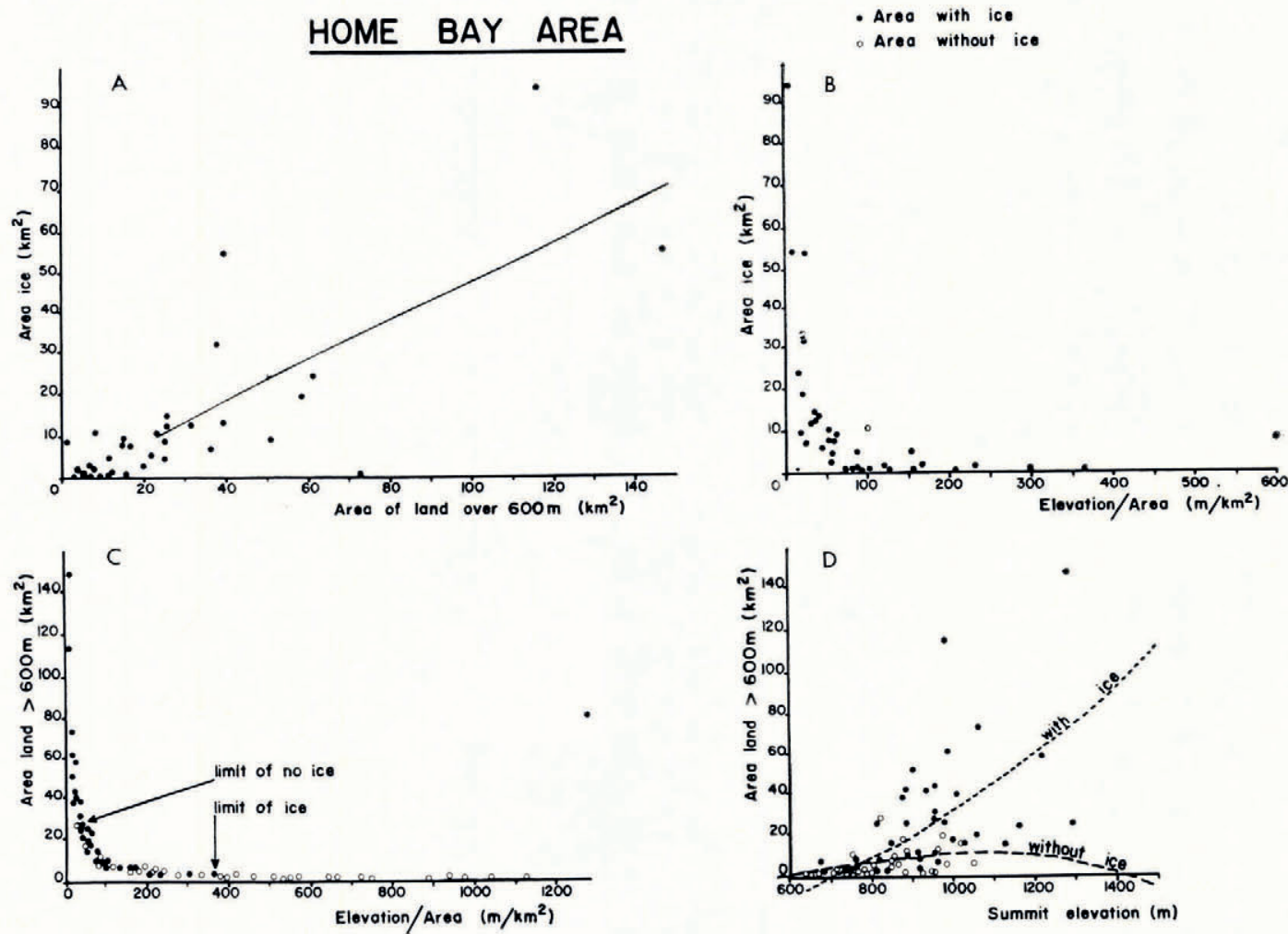

Fig. 7. Data on glacierization for Home Bay. A: area of glacierization compared with area of land over 6oo $m$ a.s.l. B: area of ice and the ratio of elevation $(\mathrm{m}) /$ area above $600 \mathrm{~m}$ a.s.l. $\left(\mathrm{km}^{2}\right) . C$ : the presence or absence of glacierization in relation to area of land over 6oo $m$ a.s.l. and the ratio of elevation $(m) / a r e a$ above $600 \mathrm{~m}$ a.s.l. $\left(\mathrm{km}^{2}\right)$. D: the presence or absence of glacierization in relation to summit elevation and the area of land over $600 \mathrm{~m}$ a.s.l.

The last two graphs on Figures 7 and 8 illustrate the relationship between summit elevation, area of land above $600 \mathrm{~m}$ a.s.l. and presence or absence of glacier ice. Considerable spread of values occurs and the upper and lower limits of glacierization are not as easily defined as on Figures $7(\mathrm{c})$ and $8(\mathrm{c})$. Second-order polynomials are plotted for the with- and without-ice condition. Coefficients of determination are low, 33 and $24 \%$ respectively, for Home Bay although less scatter is observed on Figure 8 and the equivalent coefficients have values of 6 I and $25 \%$. In both Home and Okoa Bays, summit elevations of $\mathrm{I} 000 \mathrm{~m}$ a.s.l. are generally glacierized to some extent. 
Quantitative information on the effect of area and summit elevation on the extent (area) of ice may be gained by using multiple regression techniques. In the present three-variable situation we can plot the data in the form of trend surfaces. The area of ice in the two areas has been related to combinations of (a) areas of land above $600 \mathrm{~m}$, (b) elevation/area ratio, and (c) summit elevation, but only one combination significantly increased the coefficient of determination over the simple two-dimensional analysis. This result was obtained for Okoa Bay data relating area of ice $(Z)$ to land area over $600 \mathrm{~m}(X)$ and summit elevation $(Y)$. A reduction in the total sum of squares of $71.21 \%$ was obtained with $10 \%$ of this attributable to the addition of the second independent variable. The least-squares equation is:

$$
z=0.0858 X+0.0154 \gamma-15.046
$$

where $Z$ is in $\mathrm{km}^{2}, X$ in $\mathrm{km}^{2}$ and $Y$ is in meters.
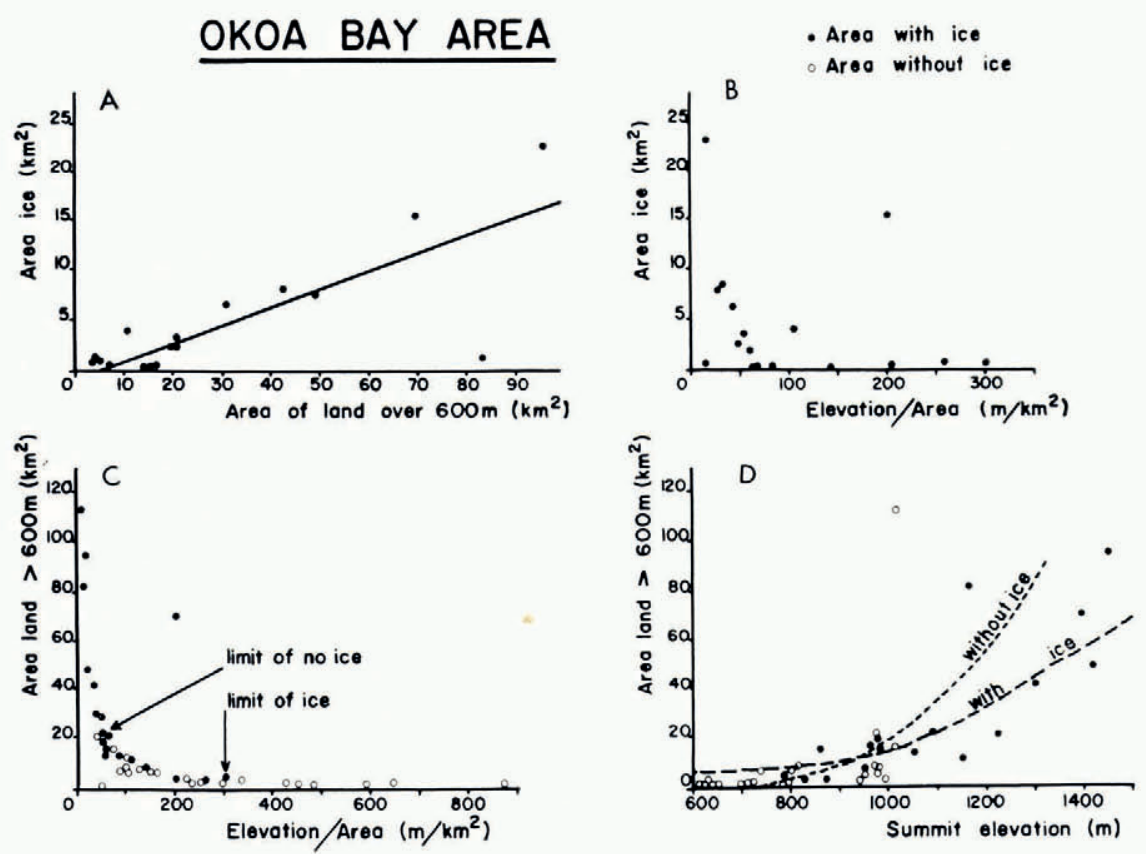

Fig. 8. Data on glacierization for Okoa Bay. A: area of glacierization compared with area of land over 6oo $m$ a.s.l. B: area of ice and the ratio of elevation $(\mathrm{m}) /$ area above $600 \mathrm{~m}$ a.s.l. $\left(\mathrm{km}^{2}\right)$. C : the presence or absence of glacierization in relation to area of land over $600 \mathrm{~m}$ a.s.l. and the ratio of elevation $(\mathrm{m}) /$ area above $600 \mathrm{~m}$ a.s.l. $\left(\mathrm{km}^{2}\right)$. D: the presence or absence of glacierization in relation to summit elevation and the area of land over $600 \mathrm{~m}$ a.s.l.

STUdy of CIRQUe ORIENTATIONS, ELEVATIONs, AND GRADIENTS

Despite the absence of knowledge on the controls of present forms there have been various attempts by glaciologists and geomorphologists to interpret glacial features in a geologic/ climatic context. This has happened to a degree with the use of cirque orientations and elevations (reviews of usage are included in Charlesworth (1957) and Flint (1957)) while in some cases present and past distributions have been compared (Porter, 1964, for example).

Recognition of cirques on air photographs is usually easy if they have the mature "armchair" appearance. Identification is less easy if the cirques are immature, degraded or partially drowned. The parameters measured from the air photographs at each site are listed in Table II. There are many specific differences between the cirques in Home Bay and those in 
Okoa Bay (Figs. 9 and ro). In Home Bay, many cirques are drowned and few, if any, are filled by an individual glacier. In several areas a cirque is now partially hidden under the cover of an ice field. By comparison there are many more cirques in the Okoa Bay area, over half contain glaciers or ice patches, and none appear to be drowned. These differences further emphasize a significant contrast in both past and present glacierization.

Cirques in the Okoa Bay area

Figure 9 shows the orientation and lip elevation of all cirques in the area divided into three categories - containing glaciers, containing ice patches, and empty.

The orientation of the 49 cirques which contain glaciers (Figure $9(a)$ ) is restricted to azimuths between $3 \mathrm{IO}^{\circ}$ eastward to $145^{\circ}$. The median orientation lies at $15^{\circ}$ although the distribution is multimodal with modes at $325^{\circ}, 30^{\circ}$ to $50^{\circ}$, and $135^{\circ}$ with slightly over $50 \%$ occurring between $360^{\circ}$ and $60^{\circ}$. The cirques range in elevation from $460 \mathrm{~m}$ to $\mathrm{I} 25^{\circ} \mathrm{m}$ a.s.l. with a median elevation of $800 \mathrm{~m}$ a.s.l.

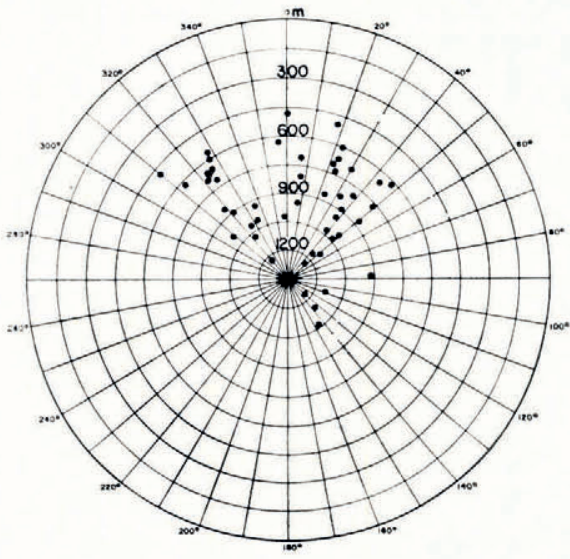

(a)

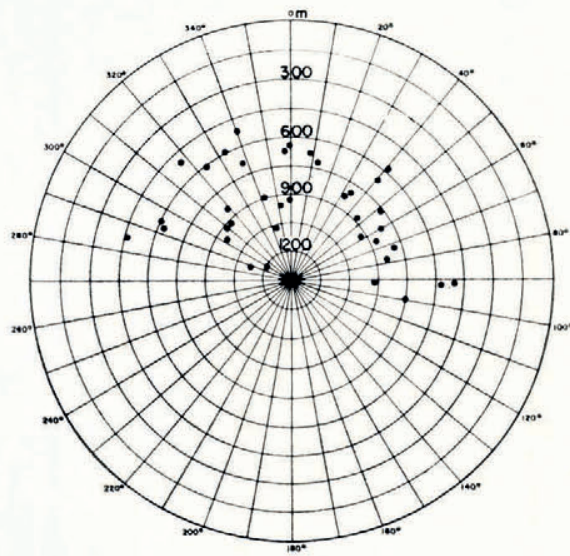

(b)

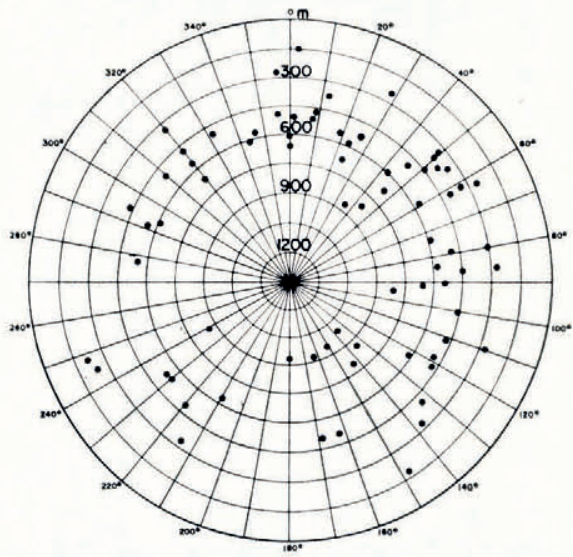

(c)

Fig. 9. Cirque data for Okoa Bay: A: orientation and elevation of cirque floors containing glaciers. B: orientation and elevation of cirque floors containing ice patches. $G$ : orientation and elevation of all cirque floors in the Okoa Bay map area (as defined in Figure 3). 
Cirques with ice patches (Fig. 9(c)) have a more even orientation distribution and occur clockwise from $285^{\circ}$ to $100^{\circ}$. The elevation of these 37 cirques is slightly more restricted than those with glaciers. The lowest recorded elevation is $450 \mathrm{~m}$ and the highest $\mathrm{I} 200 \mathrm{~m}$ a.s.l.; about $66 \%$ occur between 600 and $900 \mathrm{~m}$ a.s.l.

It is surprising in view of the extreme climatic conditions of east Baffin Island that out of a total of 163 cirques, 77 are unoccupied by glaciers or ice patches. The orientation/elevation diagram Figure 9(c) shows that cirques glaciers must have been less restricted at some time in the past. Elevation of these empty cirques ranges from $150 \mathrm{~m}$ to $\mathrm{I} 050 \mathrm{~m}$ a.s.l. and they face in all directions; in fact $39 \%$ are oriented toward the south. The predominant direction of orientation is still, however, the north-east quadrant (i.e. from $360^{\circ}$ to $090^{\circ}$ ) with $42 \%$ of the observed distribution. The median elevation is about $500 \mathrm{~m}$ a.s.l.; it is noticeable that only cirques facing south-east lie above $900 \mathrm{~m}$ a.s.l.

Such diagrams are useful and have been employed by other workers (e.g. Seddon, 1957; Temple, 1965), but they fail to take into account geographic trends of lip elevation. Such trends were analysed from coastal Labrador (Andrews, $1965[\mathrm{~b}]$ ) by grouping the cirques into

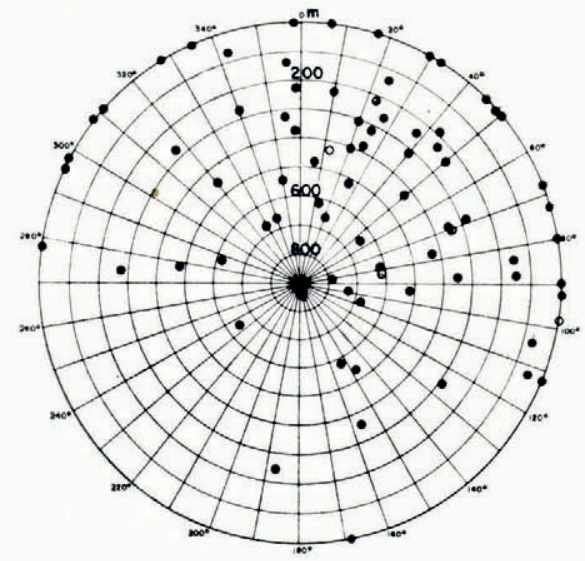

(a)

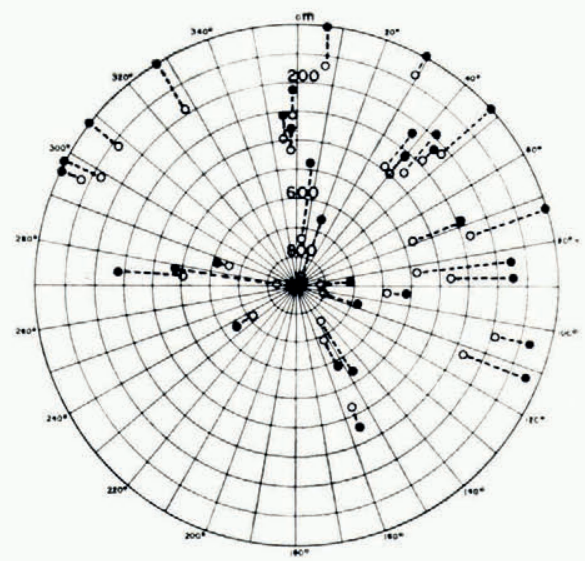

(b)

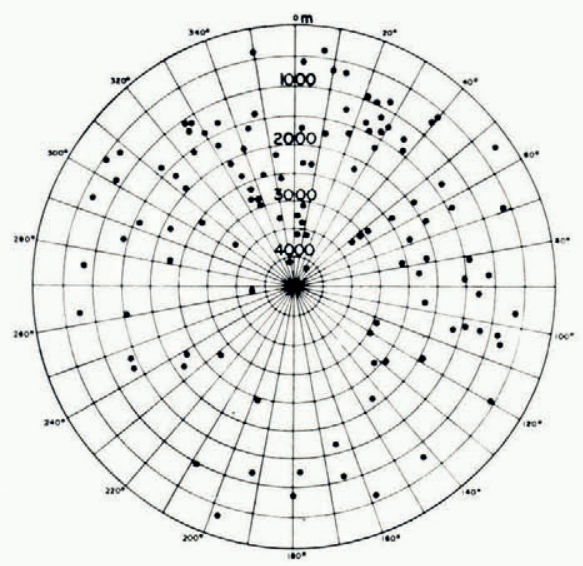

(i)

Fig. 1o. Cirque data for Home Bay: A: orientation and elevation of all cirque floors. B: orientation and elevation of cirque floors $\bigcirc$ and back walls in the Nudlung map area (Fig. 2, lower right). C: orientation and length of glaciers descending from ice fields or ice caps. 
classes on the basis of location. Figure 3 presents a more sophisticated approach, based on trend surface techniques, similar to that used recently for Tasmania by Peterson and Robinson (1969). Table IV lists pertinent facts from the trend surface computations. It was found that the trend surfaces of cirques with glaciers and with ice patches are nearly identical, reflecting comparable gradients and orientations of the cirque floor "surface". Both trends are significant in a statistical sense. The linear surfaces strike $120^{\circ}$ to $300^{\circ}$ and dip $030^{\circ}$ at $17 \mathrm{~m} \mathrm{~km}^{-1}$. The standard error on the surface for cirques with ice patches is $\pm 95 \mathrm{~m}$ and the maximum residual is $+240 \mathrm{~m}$; the respective values for cirques with glaciers are $\pm \mathbf{I} 35$ and $-320 \mathrm{~m}$. Figure 9 shows that the gradient of empty cirques facing southward is similar to that of occupied cirques but is on the average $200 \mathrm{~m}$ lower at any site. The trend is also quite similar (Fig. 3) differing by about $5^{\circ}$. The standard error is $\pm 15^{\circ} \mathrm{m}$ with a maximum residual of $+240 \mathrm{~m}$.

Table IV. Trend surface analysis of Okoa Bay data

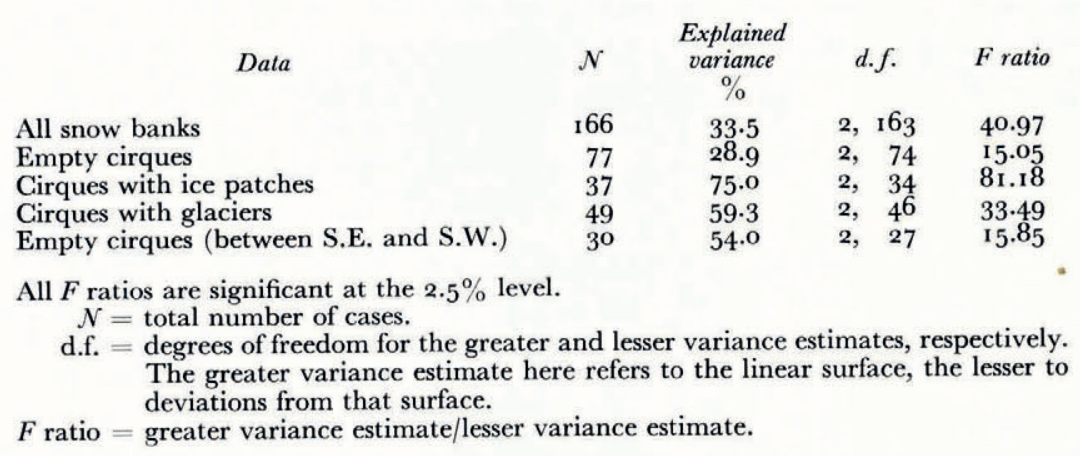

In review, it is apparent that there is a considerable difference in the orientation of cirques presently containing ice masses and those which are empty. The range in elevation of the cirques, as seen on Figure 9 , is in part due to an increase in elevation of the cirque floor surface toward a bearing of $210^{\circ}$. This trend is linear. It was found that the fitting of higher-order surfaces to the data resulted in only small increases in the variance accounted for. The trend of the cirque-floor surface is thus nearly parallel to the regional trend of the coast and summit surface (Fig. I).

\section{Cirques in the Home Bay area}

Figure to indicates the direction and elevation of all Home Bay cirques. The median azimuth of cirque distribution (Fig. IO(a)) is towards $30^{\circ}$ and there is a significant lack of features between $180^{\circ}$ and $270^{\circ}$. Cirque floors are markedly lower than in Okoa Bay with a median altitude of $300 \mathrm{~m}$. A large number (22) of cirque floors are at present below sea-level and this fact highlights the problem of the association between cirque glaciation and erosion and the successive glaciations. Unlike their counterparts in Okoa Bay, the Home Bay cirques are either totally devoid of glacier ice or, in the case of the Nudlung area (Fig. 2, lower right), they are filled with glacier ice that originates from the mountain ice fields, so that it is only the form of the ice surface that allows their identification. The absence of individual small cirque glaciers around Home Bay is one of the major differences between the two areas. The reasons for this contrast are not obvious.

The distribution of cirques in the Nudlung area of Home Bay (Fig. Io(b)) is similar to that in the wider area-cirques are lacking in the south-east quadrant and a number are drowned. The development of the features is partly indicated by the heights of their back walls which vary from $100 \mathrm{~m}$ to $35^{\circ} \mathrm{m}$. 
Trend-surface analyses were performed on the above data for the Nudlung map (Fig. 2, lower right) and the Ekalugad map (Fig. 2, top). Table V contains the basic information on the analyses while Figures 2 and io show the results graphically. The statistically significant linear trends on the distribution of all cirques and all snow-banks parallel each other over the area of the two map units. In the Nudlung area the surfaces dip $30^{\circ}$ at $10.7 \mathrm{~m} \mathrm{~km}^{-1}$, a lesser gradient than computed for Okoa Bay. The intersection of the cirque and snow-bed surface is not significant in the context of the standard errors. The gradient of the cirque-floor surface along Ekalugad Fiord (Fig. I I, Ekalugad map, Fig. 2) is much smaller $\left(6 \mathrm{~m} \mathrm{~km}^{-1}\right)$ with the surface dipping toward $105^{\circ}$. Data for the two maps were run separately and it is noticeable that the plotted trends intersect at a sharp angle. Both trends are approximately at right angles to the fiords.

Table V. Trend surface analysis of Home Bay data

$\begin{array}{lrcrrr} & \mathcal{5} & \begin{array}{c}\text { Explained } \\ \text { variance } \\ \%\end{array} & \text { d.f. } & \text { F ratio } \\ \text { Nudlung Map } & & & & & \\ \quad \text { All cirques } & 42 & 56.98 & 2, & 39 & 25.73 \\ \text { All snow-banks } & 136 & 38.71 & 2, & 133 & 41.99 \\ \text { S.W. snow-banks } & 40 & 19.83 & 2, & 37 & 4.57 \\ \text { Ekalugad Map } & 36 & 32.8 & 2, \quad 33 & 8.08 \\ \quad \text { All cirques } & 177 & 16.1 & 2,174 & 16.74 \\ \text { All snowbanks } & 27 & 24.3 & 2, \quad 24 & 6.27 \\ \text { S.W. snow-banks } & 27\end{array}$

All $F$ ratios are significant at the $2.5 \%$ level. Symbols as in Table IV.

\section{ICE-FIELd GLACIERS IN THE Home BAy AREA}

Many of the large ice fields in the Home Bay area have one or more glaciers descending toward sea-level and these relate to a totally different glaciological milieu from that of the individual cirque glaciers. 162 glaciers of this type have been identified in the Home Bay area from air photographs and map interpretations. Various statistics on length, orientation, amount of retreat and elevation of the margins were abstracted. The long axis of the major ice fields is strongly controlled by the orientation of the fiords. In the Nudlung area the ice fields trend north-east/south-west whereas in the region of Ekalugad Fiord they are oriented east/west (Fig. 2). A simple hypothesis of glacier distribution as related to topography would suggest that in the Nudlung area they should descend toward the north-west or south-east, whereas in the Ekalugad area they should be directed toward the north or south. Table VI lists the observed distributions, while Figure $\mathrm{IO}(\mathrm{c})$ shows the total pattern of glaciers based on their direction and length. Sixty-six glaciers are directed between north-west and north-east compared with $\mathrm{I} 7$ between south-east and south-west; there is no simple topographic reason for this anomaly. Glacier lengths, measured from the junction with the main ice field, are less in the south-east and south-west quadrants, although because of the range of values there is no significant difference between the mean lengths over the four main quadrants. The mean glacier length is $2 \mathrm{~km}$, with a maximum of $9.6 \mathrm{~km}$.

Measurable retreat has been recorded on 30 (18.5\%) of the glaciers. Surprisingly, little retreat is recorded for glaciers directed between south-east and south-west and testing by $\chi^{2}$ indicates that the proportion of glaciers that have retreated is not significantly different from the expected numbers in the four main orientation sectors (Table VI). The effect of the broad, massive topography in the Ekalugad region is one possible explanation for the more even direction of the glaciers there compared with the more dissected Nudlung area. 
The amount of observable recession from recent terminal moraines (probably $\mathrm{I} 7$ th to I 9 th century) varies from nil to a maximum of I $600 \mathrm{~m}$. Approximately $20 \%$ of the glaciers show measurable recession, that is $>100 \mathrm{~m}$. This rather limited evidence for frontal retreat since a maximum within the last 250 years provides a marked contrast with the response of many Norwegian and Alpine glaciers within the same period, but accords with recent findings elsewhere in the eastern Arctic (Hattersley-Smith, 1969). The mean measured recession for the 30 glaciers was $405 \pm 180 \mathrm{~m}$ with an average recession of $8 \mathrm{I} 6 \mathrm{~m}$ for 6 glaciers in the southeast quadrant and $335 \mathrm{~m}$ for 12 glaciers in the north-east quadrant.

TAble VI. Distribution of glaciers in $45^{\circ}$ Segments

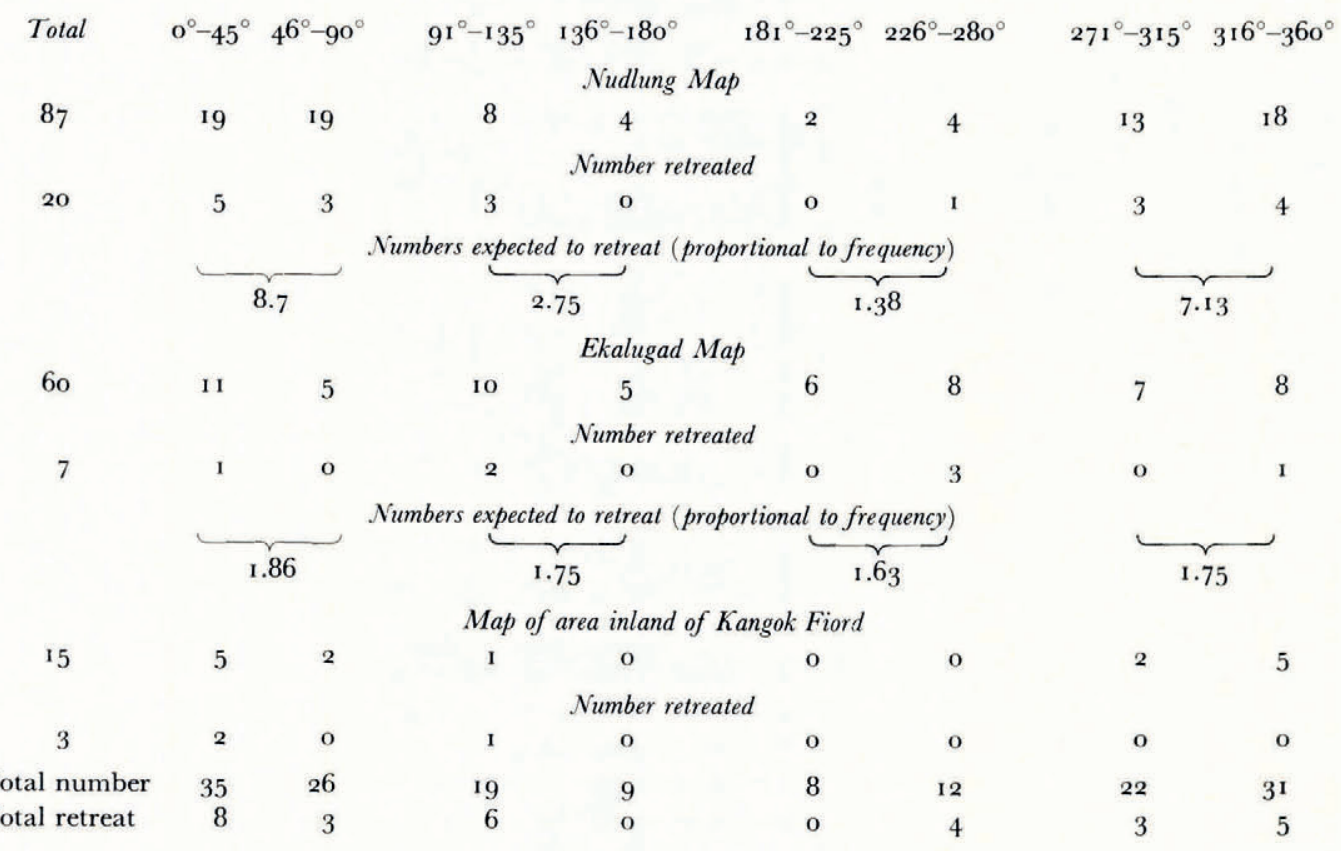

\section{Distribution OF PERMANENT SNOW-BANKS}

Small, permanent snow-banks are present throughout both areas in the lee of topographic irregularities. Variables measured (Table I) were elevation and orientation. The lowest elevation of extant snow-beds have been used (Manley, I955, for example) to derive estimates of the regional snow-line. Prominent lichen "trim lines" around many of the permanent snow-beds in our areas provide clear evidence of their recession in the recent past. In both Home and Okoa Bays permanent snow-beds are found down to near sea-level although trend surface analyses (Figs. 2 and 3 , and Tables IV and V) indicate that there is an overall increase in elevation parallel to the trend of the cirque-floor surface (see also Figure I I). In inland reaches of Okoa Bay snow-beds occur, on the average, $400 \mathrm{~m}$ below cirques containing active glaciers. A study of orientation/elevation diagrams for Home Bay indicates a clear difference between the coastal areas and those inland on the plateau. In the latter area the majority of snow-beds face south-west whereas in the former area they are oriented toward the north-east, as are the Okoa Bay features. These distributions may be the result of well differentiated wind flow patterns. Table VII shows that the most frequent wind direction at Dewar Lakes, on the inland plateau, is easterly, whereas the prevailing direction at coastal stations is west or northwest. 
On the whole, the study of snow-bed distribution does not add a great deal to the investigation, largely because these features are more or less ubiquitous given a degree of topographic irregularity.
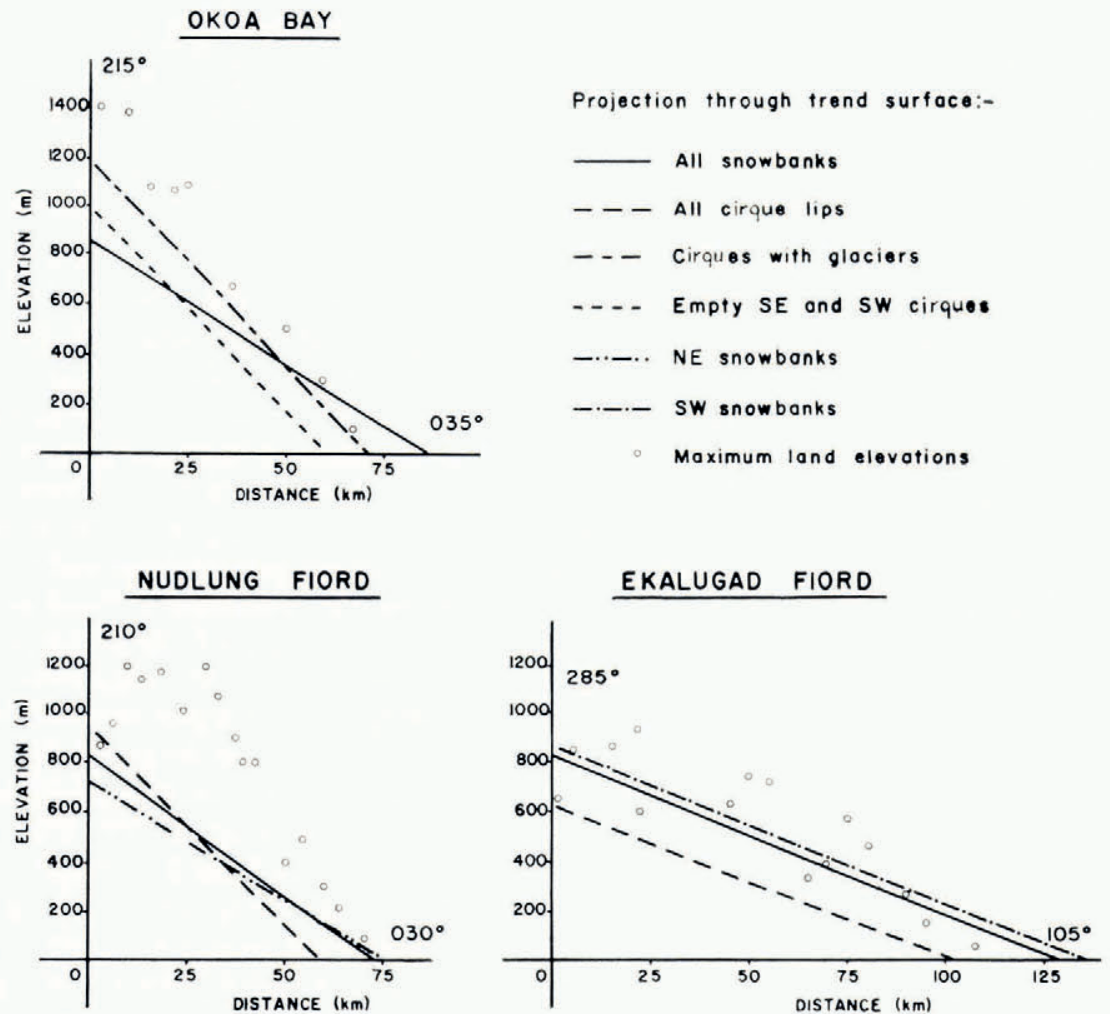

Fig. II. Profiles drawn normal to the linear trend surfaces of Figures 2 and 3 showing snow-banks, cirques with glaciers and empty cirques facing south-east and south-west in Okoa Bay, and snow-banks and cirques with glaciers in Home Bay (Nudlung Fiord, Ekalugad Fiord).

\section{Climatic considerations}

Eastern Baffin Island is far from homogeneous climatically, particularly in terms of precipitation. Table VII illustrates the decrease in frequency and amount of snowfall northward of Cape Dyer. The large totals in the Cumberland Peninsula are evidently related primarily to the greater frequency of snowfall rather than to heavier (average) falls.

The distribution of snowfall amounts would lead one to expect the opposite pattern of glacierization in Home Bay and Okoa Bay to that actually observed. Consequently, we must consider the likely ablation in the two areas. Apart from the measurements made in I953 on the Penny Ice Cap by Orvig (1954) there is no direct evidence on this question and the upland ice-cap situation is in any case not directly relevant to the problem under consideration here. The number of degree days with a mean daily temperature above $0^{\circ} \mathrm{C}$ was therefore examined. Table VII gives the average accumulated totals for ${ }_{196} \mathrm{I}-65$ at Broughton Island and Cape Dyer. The highest and lowest totals during these 5 years are shown in Table VIII. Dewar Lakes is included for comparative purposes. Although there is little difference between the highest totals, the lowest value at Cape Dyer is much above that at the other two stations. 
Table VII. Climatic data for Baffin Island

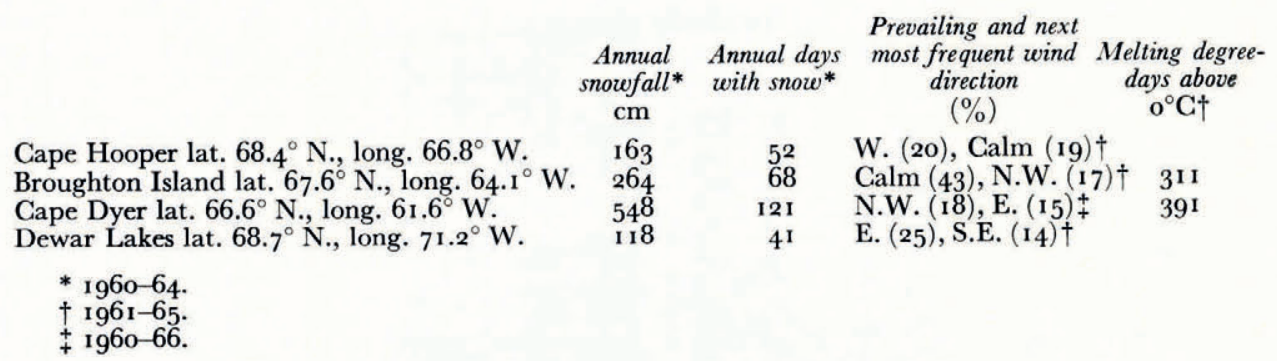

In terms of ablation equivalent only a very crude estimate is possible at present. Pysklywec and others (1968) obtained an average daily snow melt of 0.04 inch (water equivalent) per day-degree $\mathrm{F}$ above $27.6^{\circ} \mathrm{F}\left(\approx 0.18 \mathrm{~cm}\right.$ per day-degree $\mathrm{C}$ above $-2.6^{\circ} \mathrm{G}$ ) in New Brunswick, while the U.S. Army Corps of Engineers (1956) cite values of $\approx 0.05$ inch per day-degree $\mathrm{F}$ above $32^{\circ} \mathrm{F}\left(\approx 0.23 \mathrm{~cm}\right.$ per day-degree $\mathrm{C}$ above $0^{\circ} \mathrm{C}$ ) in the Sierra Nevada. At an elevation of $300 \mathrm{~m}$ on the Sverdrup Glacier, Devon Island, during 1963 , Keeler ( 1964 ) estimated the much higher rate of $0.47 \mathrm{~cm}$ (water equivalent) per day-degree $\mathrm{C}$ above $0^{\circ} \mathrm{C}$. Obviously, the figure will vary from year to year and place to place but, in view of the fact that the only reasonably reliable long-period data in the Arctic are usually temperature records, it seems worthwhile seeking empirical relationships of this type as a first estimate of spatial variations in ablation amounts. Using a figure of $0.2 \mathrm{~cm}$ per day-degree $\mathrm{C}$ above $0^{\circ} \mathrm{C}$, we obtain an ablation equivalent of $62 \mathrm{~cm}$ water equivalent at Broughton Island and $78 \mathrm{~cm}$ water equivalent at Cape Dyer. Using Keeler's factor, these figures become $146 \mathrm{~cm}$ and $18 \mathrm{I} \mathrm{cm}$ respectively. Both sets of estimates considerably exceed the annual snowfall converted to water equivalent (Table VII). A plot of mean monthly temperature against monthly melting (degree days total) for Cape Dyer and Broughton Island (not shown) indicates a clearly defined curvilinear relationship with negligible scatter over the greater part of the range. Only below $1^{\circ} \mathrm{C}$ (a monthly melting degree-day total $\approx 45 \mathrm{deg}$ ) does the fit become less satisfactory, with apparently different curves for each station. Using the Broughton Island curve, and assuming a mean lapse rate of $0.8 \mathrm{deg} / 100 \mathrm{~m}$ (based on temperatures recorded at Inugsuin Fiord and a temporary inland station at $c .300 \mathrm{~m}$ a.s.l. during June and July ${ }_{1967}$ (Barry, I968)), it is estimated that the mean melting degree-day total at $\mathrm{I}$ ooo $\mathrm{m}$ elevation is $\approx 20 \mathrm{deg}$, corresponding to only $\approx 5^{-10} \mathrm{~cm}$ water equivalent. Since this figure would imply a snow line much lower than is observed, it is clear that more specific information is required on temperature conditions in the coastal mountains and on ablation-temperature (or preferably ablation-radiation) relationships.

Consequently, there is no clear evidence concerning the relative importance of summer ablation and winter snowfall in maintaining the present pattern on glacierization. All that can be said is that the northward decrease in ablation appears to be proportionately smaller than the decrease in snowfall amount.

It is of course possible that the coastal stations are very unrepresentative of precipitation conditions inland. For example, total precipitation at the head of Ekalugad Fiord between 4 June and 31 August 1967 , was $22.2 \mathrm{~cm}$ (Church, 1968) compared with only $7.7 \mathrm{~cm}$ at Cape

Table VIII. Melting Degree-days

\begin{tabular}{lllll} 
& & \multicolumn{4}{c}{ Melting degree-days } \\
Broughton Island & 423 & $(\mathrm{r} 962)$ & 251 & $(\mathrm{I} 963)$ \\
Cape Dyer & $44 \mathrm{I}$ & $(\mathrm{r} 962)$ & 310 & $(1964)$ \\
Dewar Lakes & 468 & $(\mathbf{1 9 6 2})$ & 263 & $(1963)$
\end{tabular}


Hooper. The bulk of this difference occurred during August. For instance, $3.69 \mathrm{~cm}$ of rain fell at Ekalugad Fiord on 24-25 August while only $0.23 \mathrm{~cm}$ was recorded at Cape Hooper. On a day-to-day basis there is no evidence of similarity of precipitation events between the coastal stations. With reference to days with at least $0.025 \mathrm{~cm}$ precipitation in September and October $I_{9} \mathrm{I}_{\mathrm{I}}-65$, for example, the coefficient of association is only 0.69 between Cape Hooper and Broughton Island and $0.7 \mathrm{I}$ between Broughton Island and Cape Dyer. A figure $>0.90$ is required for some degree of similarity between the stations. The implication is that largescale, synoptic control of precipitation is possibly less important in this area than might be anticipated. However, it may be that local effects mask the synoptic-scale precipitation systems through the direct or indirect effects of topography and the extent of open water versus sea ice.

The synoptic patterns typical of cool summer days were examined using an arbitrary temperature criterion of mean daily temperature $<2.5^{\circ} \mathrm{C}$ at Broughton Island. 20 out of a total of 35 such cases during July $196 \mathrm{r}-65$ were associated with a low center in Davis Strait or

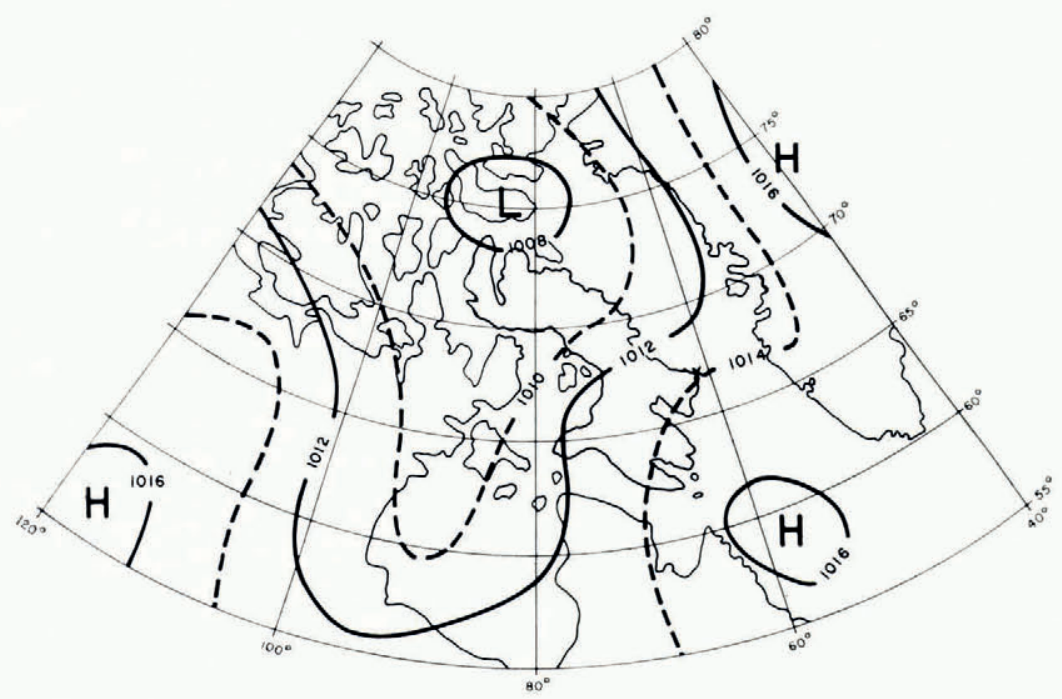

Fig. 12. Mean sea-level pressure pattern for $I_{3}$ days with a maximum air temperature $>15^{\circ} \mathrm{C}$ at Cape Dyer (marked $X$ ), $196 I-65$.

Baffin Bay and a further 5 cases with a low over Baffin Island; all patterns give an easterly flow component over the area in question. A further indicator of cool summers is lack of sunshine. Sagar ( 1966 ) has shown the significance of solar radiation for ablation in Baffin Island. He states that $70 \%$ of the melt on the Barnes Ice Cap during 1962 and almost $100 \%$ in I 963 was due to absorbed radiative energy. Selection of days with $<10 \%$ of possible bright sunshine at Frobisher during June and July $196 \mathrm{I}-65$ again show the importance of southeasterly flow with usually a low center over Hudson Strait (figures not included, see Barry and Fogarasi (1968, p. 99-103)).

As an indicator of warm summer conditions, all cases with a maximum temperature $\geqslant 15^{\circ} \mathrm{C}$ at Cape Dyer during July and August $196 \mathrm{r}-65$ were used. The mean sea-level pressure pattern for these 13 (non-consecutive) days shows high pressure over the northern Labrador Sea and south-westerly flow at Cape Dyer (Figure 12). In such a situation föhn descent might occur in the vicinity of the station, although no study of this possibility has yet been undertaken. 
Turning next to some paleoclimatic considerations, we first note that the geomorphological evidence indicates that mountain glaciers and ice caps developed in the Home Bay area only c. 2 ooo- 4 OOO years ago as the main Laurentide ice shrank and retreated on the western side of the east coast mountains (Andrews and others, 1970). Figure is outlines a model of this development based on the field evidence. This sequence suggests that when the ice-cap dome exceeded the elevation of the mountain summits the mountains were subject to sheltering with respect to moist south-westerly air flows. As the main ice retreated, however, mountain ice caps and glaciers could form. Examination of the occurrence of daily snowfalls of $>5 \mathrm{~cm}$ at Dewar Lakes in September-October $1961-65$ indeed shows a mean low-pressure center in Foxe Basin and south-westerly flow (Fig. 14), so there is some plausibility in this argument. If, however, we attempt to apply this idea to the northern part of the Cumberland Peninsula, and reason that the small extent of ice in the Okoa Bay area at the present day is caused by

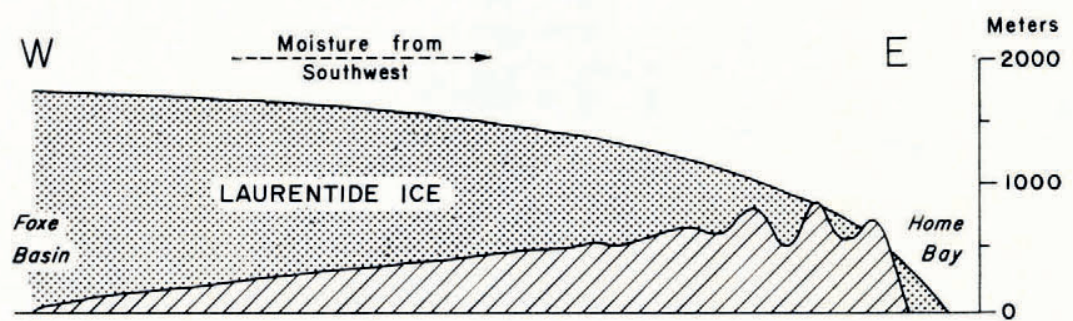

(a) ABOUT 9000 YEARS AGO
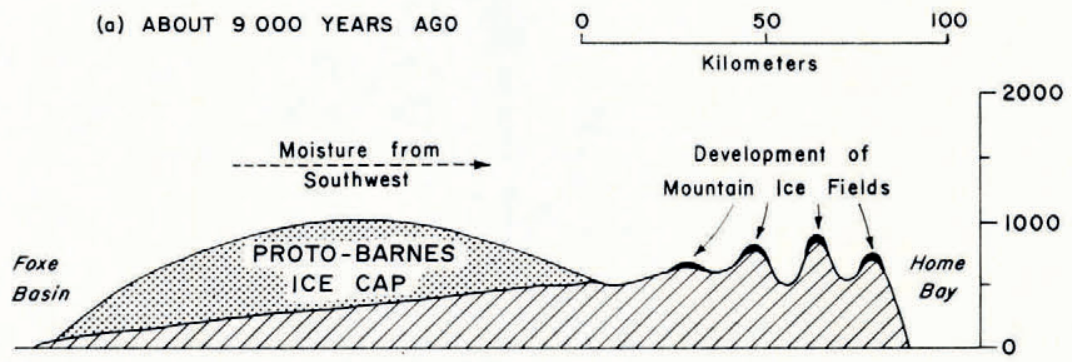

(b) ABOUT 4000 YEARS AGO

Line of Section Approximately $68.7^{\circ} \mathrm{N}$.

Fig. 13. A model for the development of mountain glaciers and ice caps in the Home Bay area. (Note: the present Barnes Ice Cap is situated north of the line of section, approximately lat. $68.7^{\circ} \mathrm{N}$.).

sheltering effects of the Penny Ice Cap with respect to south-westerly air flow, the case breaks down. Figure i5 shows that heavy snowfalls at Broughton Island $(>5 \mathrm{~cm} / 24 \mathrm{~h}$ during September-October $196 \mathrm{I}-65)$ are associated with a low over the Davis Strait area and easterly flow at the coast. A similar picture is obtained for days with $>12.7 \mathrm{~cm}(5$ in) snowfall at Cape Dyer (not shown). The overall relative importance of south-west and south-east sources of accumulation in this and other parts of Baffin Island remains to be determined. This work is in progress at the present time as a continuation of the study referred to earlier by Barry and Fogarasi (ig68).

With reference to the data on cirque orientation in the two areas it was noted above that there is a general northerly and easterly exposure of cirques occupied by glaciers. This is not obviously related to wind drift since the frequency of south and south-west winds is only $8 \%$ at Broughton Island, $13 \%$ at Cape Hooper and $18 \%$ at Cape Dyer. However, more information on the direction of the dominant winds in winter and particularly on the local wind pattern is 


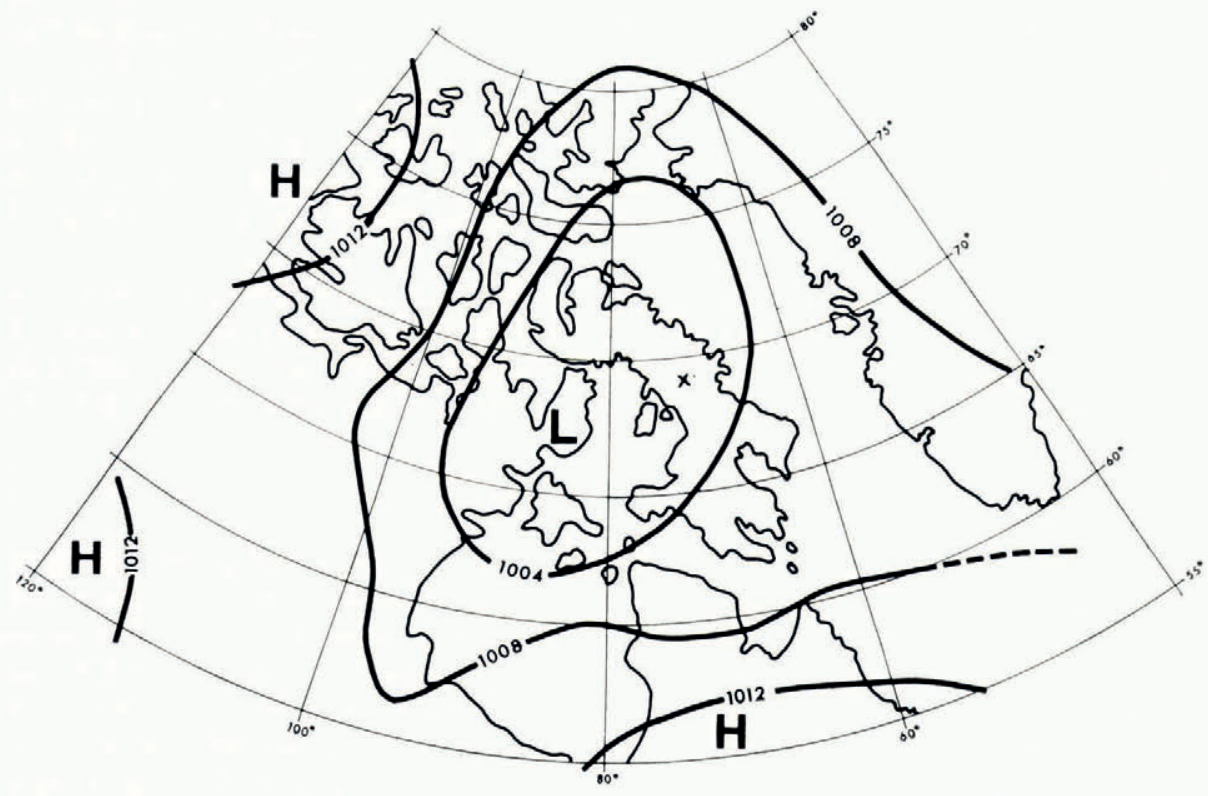

ㄴ, Miles, 500

Fig. 14. Mean sea-level pressure pattern for 13 days with snowfall $>2$ inch $(5 \mathrm{~cm})$ at Dewar Lakes (marked X), SeptemberOctober $I_{96}{ }_{1}-65$.

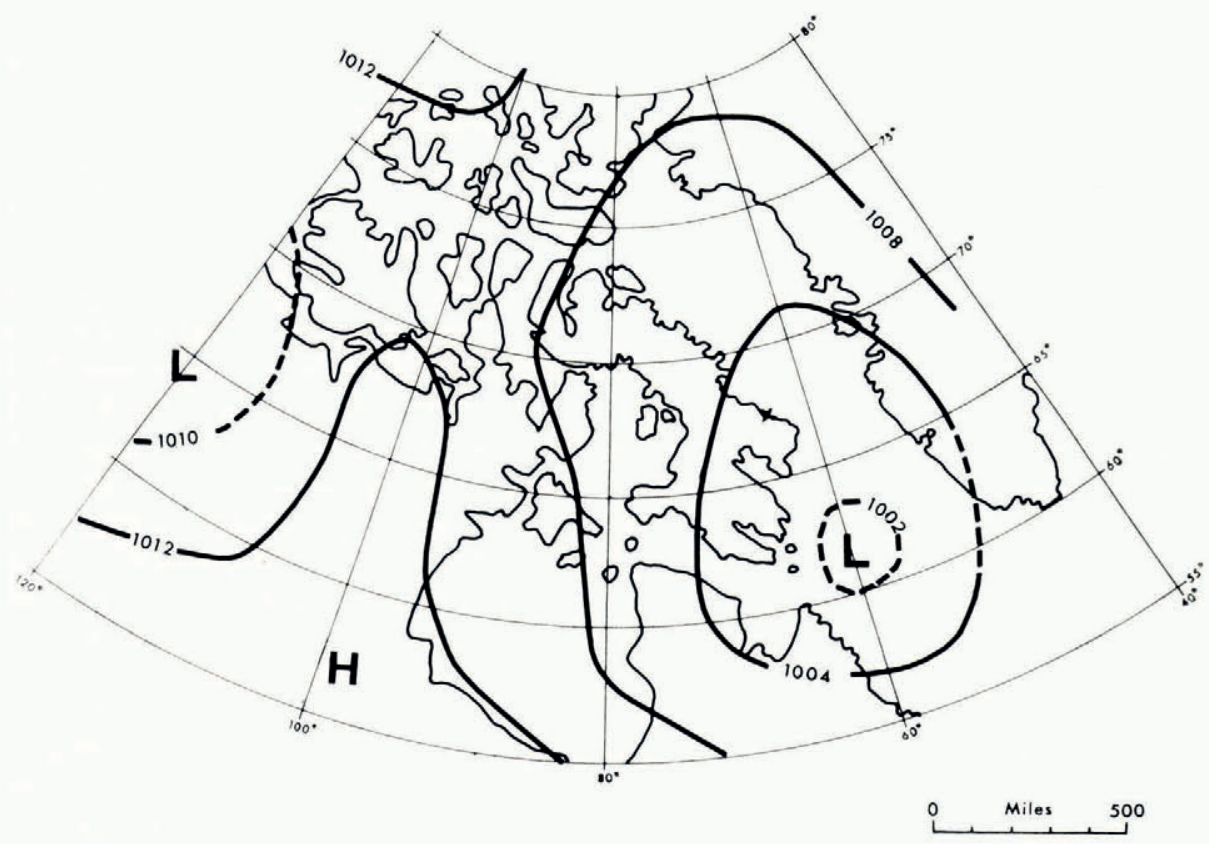

Fig. 15. Mean sea-level pressure pattern for 37 days with snowfall $>2$ inch $(5 \mathrm{~cm})$ at Broughton Island $($ marked X), SeptemberOctober $1961-65$. 
required. When we consider the distribution of empty cirques in Okoa Bay (Fig. 9) it is noticeable that they are not only lower, but $39 \%$ have a southerly orientation. The $200 \mathrm{~m}$ lowering of the trend surface of cirque elevation (Fig. I I) may reflect a summer temperature decrease of $\mathrm{I} . \mathrm{O}^{\circ}-\mathrm{I} .5^{\circ} \mathrm{C}$, or may imply greater summer cloudiness. The former is perhaps more likely since the latter would require greater frequency of disturbances, which at the same time would be accompanied by more frequent warm, moist air masses in the warm sector of the depressions. The effect of isostatic depression has also to be considered in this context and this factor is discussed below.

It is significant that there is no association between orientation and glacier retreat in the Home Bay area. The absence of retreat of south-facing glaciers may reflect the influence of drifting and blowing snow with northerly winds, although the latter are not especially frequent $-30 \%$ from north-west, north and north-east at Broughton Island and $31 \%$ at Cape Hooper.

\section{Discussion}

The results fail to show any clear and simple relationship between present climate and glacierization in these two areas of Baffin Island. In part this may reflect the use of climatic data from stations that inadequately represent the glacier environments. Another consideration, however, is the lag response of ice bodies to climatic changes (see Bryson and Wendland, 1967, fig. 70). This response operates over the various time scales shown in Table IX and it seems possible that some of the contrast between the two areas reflects differential lag effects between the ice fields and ice caps of Home Bay, on the one hand, and the glaciers of Okoa Bay on the other.

TABle IX. Relationship of Different time scales of Climatic Change AND the Response LeVel OF GLACIERS

Wave length order

1

2

3

4

Approximate time scale
year
$10^{4}$ to $3 \times 10^{4}$
$10^{2}-10^{3}$
30
$1-10$

Glacier type

Laurentide ice sheet, local mountain glaciation as shown by abandoned cirques

Ice caps, fields and cirque glaciers

Ice patch

Snow-bed

In the scheme of Table IX it is assumed that topography represents an essentially constant "platform" on which is imposed the regional climate. Nevertheless, in coastal zones which have been subjected to Pleistocene glaciation the present elevation of abandoned cirques and other features has to take into consideration the isostatic depression of the land surface under the load of the Pleistocene ice sheets. In our area, consideration of theoretical ice-cap profiles and probable isostatic depression indicates that elevations were between 200 and $80 \mathrm{~m}$ lower than today, relative to present sea-level. In the Home Bay area, for example, the sealevel in Cockburn time (c. 8 ooo B.P.) was probably still $60 \mathrm{~m}$ higher than today. The maximum elevation $(790 \mathrm{~m})$ of a lateral moraine system in the area can be used to give a lower limit on the equilibrium line of the time. Hence, the snow line inferred from this moraine was at least $790-60 \mathrm{~m}=730 \mathrm{~m}$ a.s.l. Today's snow line is considered to be around $65^{\circ} \mathrm{m}$ from field observations and yet there is almost certainly less snow and ice cover at the present time. This difference may represent the effect of a lag in response of the Cockburn ice bodies from a more severe pre-Cockburn climate, but there is at present no means of testing this hypothesis.

This study has undoubtedly raised more questions than it has answered and most of the answers must be sought in the field. A field study of selected cirques in the Okoa Bay region is in fact being undertaken in 1969 and 1970 . It is clear that the present-day relationships 
between the degree of glacierization and the climatic and topographic controls are far from being understood. The many paradoxical relationships that have been found and the rather negative conclusions emphasize the need for caution on the part of those who attempt to interpret past distributions in terms of simple climatic patterns. Many of the interpretations that have been made in the realm of glacier-climate inter-relationships would appear from the present evidence to be insecurely based. However, in spite of the uncertainties in the interpretation of the results, the factual information on the area is considered to provide a valuable basis for future investigations. A more extensive application of the techniques used here to other areas of the eastern Canadian Arctic should be very rewarding.

\section{Acknowledgements}

The work reported in this paper was initiated by the authors in the former Geographical Branch, Department of Energy, Mines and Resources. It was continued by Andrews and Drapier as members of the Geological Survey of Canada. We would like to acknowledge the research assistance of Miss Sally Wykes during the 1967 summer and to thank Dr J. D. Ives for reading this paper.

\section{REFERENGES}

Ahlmann, H. W. 1948. Glaciological research on the North Atlantic coasts. London, Royal Geographical Society. (R.G.S. Research Series, No. I.)

American Geographical Society. 1958. Geographic study of mountain glaciation in the northern hemisphere. Department of Exploration and Field Research. Contract DAI9-I29-QM-409. Part I. New York, American Geographical Society.

American Geological Institute. 1957. Glossary of geology and related sciences. Washington, D.C., American Geological Institute. (Publication No. 501.)

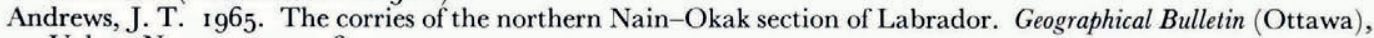
Vol. 7, No. 2, p. 129-36.

Andrews, J. T. 1966. Pattern of coastal uplift and deglacierization, west Baffin Island, N.W.T. Geographical Bulletin (Ottawa), Vol. 8, No. 2, p. 174-93.

Andrews, J. T. 1969. Importance of the radiocarbon standard deviation in determining relative sea levels and glacial chronology from east Baffin Island. Arctic, Vol. 22, No. I, p. 1 $3^{-24}$.

Andrews, J. T., and Webber, P. J. 1964. A lichenometrical study of the northwestern margin of the Barnes Ice Cap: a geomorphological technique. Geographical Bulletin (Ottawa), No. 22, p. 80-104.

Andrews, J. T., and others. Unpublished. Late glacial chronology and glacio-isostatic recovery-Home Bay, by J. T. Andrews, J. T. Buckley and J. H. England. [Written i97o.]

Baird, P. D., and others. 1950. Baffin Island expedition, 1950; a preliminary report, by P. D. Baird and other members of the expedition. Arctic, Vol. 3 , No. 3, p. 130-49.

Barry, R. G. 1968. Meteorological field program. (In North-central Baffin Island field report 1967. Canada. Department of Energy, Mines and Resources. Inland Waters Branch. Water Survey of Canada. Report Series No. 2, p. $103^{-13}$.)

Barry, R. G., and Fogarasi, S. 1968. Climatology studies of Baffin Island, Northwest Territories. Canada. Department of Energy, Mines and Resources. Inland Waters Branch. Technical Bulletin No. ${ }_{3} 3$.

Bryson, R. A., and Wendland, W. M. 1967 . Tentative climatic patterns for some late-glacial and postglacial episodes in central North America. (In Mayer-Oakes, W. J., ed. Life, land and water. Winnipeg, Anthropology Department, University of Manitoba, p. 271-98. (Occasional Papers, No. 1.))

Bryson, R. A., and others. I969. Radiocarbon isochrones on the disintegration of the Laurentide ice sheet, by R. A. Bryson, W. M. Wendland, J. D. Ives and J. T. Andrews. Arctic and Alpine Research, Vol. I, No. I, p. I-I3.

Charlesworth, J. K. 1957. The Quaternary era, with special reference to its glaciation. London, Edward Arnold. 2 vols.

Church, M. 1968. Study of clastic sedimentation in Ekalugad Fiord, Baffin Island: preliminary report-1967. (In North-central Baffin Island field report 1967. Canada. Department of Energy, Mines and Resources. Inland Waters Branch. Water Survey of Canada. Report Series No. 2, p. 49-69.)

Falconer, G. I962. Glaciers of northern Baffin and Bylot Islands, N.W.T. Canada. Department of Mines and Technical Surveys. Geographical Branch. Geographical Paper No. 33.

Falconer, G., and others. 1965. Major end moraines in eastern and central Arctic Canada, by G. Falconer, J. D. Ives, O. H. Loken and J. T. Andrews. Geographical Bulletin (Ottawa), Vol. 7, No. 2, p. 137-53.

Flint, R. F. [ [ ${ }^{1}$ 1957.] Glacial and Pleistocene geology. New York, John Wiley and Sons, Inc.

Forbes, A. 1938. Northernmost Labrador mapped from the air. American Geographical Society. Special Publication No. 22. 
Harrison, D. A. 1964. A reconnaissance glacier and geomorphological survey of the Duart Lake area, Bruce Mountains, N.W.T. Geographical Bulletin (Ottawa), No. 22, p. 57-71.

Harrison, D. A. I 666 . Recent fluctuations of the snout of a glacier at McBeth Fiord, Baffin Island, N.W.T. Geographical Bulletin (Ottawa), Vol. 8, No. 1, p. 48-58.

Hattersley-Smith, G. I 969 . Glacial features of Tanquary Fiord and adjoining areas of northern Ellesmere Island, N.W.T. Journal of Glaciology, Vol. 8, No. 52, p. 23-5o.

Keeler, C. M. 1964 . Relationship between climate, ablation and run-off on the Sverdrup Glacier, I963, Devon Island, N.W.T. Arctic Institute of North America. Research Paper No. 27.

King, C. A. M. ig69. Glacial geomorphology and chronology of Henry Kater Peninsula, east Baffin Island, N.W.T. Arctic and Alpine Research, Vol. I, No. 3, p. 195-212.

Loken, O. H. I 666 . Baffin Island refugia older than 54,00o years. Science, Vol. 143, No. 3742, p. I378-8o.

Manley, G. 1955. On the occurrence of ice domes and permanently snow-covered summits. Fournal of Glaciology, Vol. 2, No. 17, p. $453-56$.

Orvig, S. 1954. Glacial-meteorological observations on icecaps in Baffin Island. Geografiska Annaler, Årg. 36, Ht. 3-4, p. 193-318.

Ostrem, G. I966. The height of the glaciation limit in southern British Columbia and Alberta. Geografiska Annaler, Vol. $48 \mathrm{~A}$, No. 3 , p. $126-38$.

Ostrem, G., and others. 1967. Glacio-hydrology, discharge and sediment transport in the Decade Glacier area, Baffin Island, N.W.T., by G. Østrem, C. W. Bridge and W. F. Rannie. Geografiska Annaler, Vol. 49A, Nos. 2-4, p. 268-82.

Peterson, J. A., and Robinson, G. I969. Trend surface mapping of cirque floor levels. Nature, Vol. 222, No. 5 188, p. $75-76$.

Porter, S. C. 1964. Composite Pleistocene snow line of Olympic Mountains and Cascade Range, Washington. Geological Society of America. Bulletin, Vol. 75, No. 5, p. 477-82.

Pysklywec, D. W., and others. 1968. Snowmelt at an index plot, [by] D. W. Pysklywec, K. S. Davar [and] D. I. Bray. Water Resources Research, Vol. 4, No. 5, p. 937-46.

Sagar, R. B. 1966. Glaciological and climatological studies on the Barnes Ice Cap, 1962-64. Geographical Bulletin (Ottawa), Vol. 8, No. I, p. 3-47.

Seddon, B. 1957. Late-glacial cwm glaciers in Wales. Journal of Glaciology, Vol. 3, No. 22, p. 94-99.

Temple, P. H. ig65. Some aspects of cirque distribution in the west-central Lake District, northern England. Geografiska Annaler, Vol. 47A, No. 3, p. 185-93.

U.S. Army. Corps of Engineers. 1956. Snow hydrology. Portland, Oregon, U.S. Army. Corps of Engineers.

Ward, W. H., and Baird, P. D. r 954 . Studies in glacier physics on the Penny Ice Cap, Baffin Island, I953. Part I: a description of the Penny Ice Cap, its accumulation and ablation. Journal of Glaciology, Vol. 2, No. I5,

Weidick, A. 1968 . Observations on some Holocene glacier fluctuations in West Greenland. Meddelelser om Gronland, Bd. 165, Nr. 6. 